\title{
HET MIDDELBAAR ONDERWIJS VOOR MEISJES IN 1876.
}

Het is juist zeven jaren geleden, dat ik onder dergelijken titel als de bovenstaande, in dit Tijdschrift een opstel plaatste, waarin de behoefte aan een beter onderwijs voor meisjes van 12 tot 18 jaren werd aangetoond en tevens een plan voor middelbare scholen, geschikt om in die behoefte te voorzien, werd ontwikkeld. Wellicht is het mij gelukt door die beschouwingen aan een hoogstbelangrijke kwestie, welke toen de aandacht van menigeen bezig hield, eene meer praktische richting te geven. Op dat oogenblik toch was er nog slechts éene middelbare school voor meisjes in werking, namelijk die te Haarlem; te Arnhem werden plannen gemaakt, te Amsterdam was de kwestie, of er eene zou worden opgericht, aan de orde gesteld. In "de Tijdspiegel" en andere tijdschriften was reeds de middelbare school voor meisjes ter sprake gebracht; verschillende brochures verschenen, die meer of minder met het onderwerp in verband stonden; de aandacht was vrij algemeen op de zaak gevestigd. Behalve in de bovengemelde gemeenten kwam zij weldra ter sprake te Rotterdam, Dordrecht, Deventer en Groningen, waar er in 1871 of 1872 geopend werden; ook te 's Gravenhage, Goes en 's Hertogenbosch werden plannen gemaakt, die echter in duigen vielen, het eerste wegens totale absentie van belangstelling bij het Haagsche gemeentebestuur, de andere omdat de toenmalige Minister van Binnenlandsche Zaken, de heer Thоввеске, weinig gezind bleek te zijn tot geldelijke ondersteuning, zonder welke in de meeste plaatsen het tot stand komen dier betrekkelijk vrij kostbare inrichtingen niet wel mogelijk was. Een amendement van de Heeren Joncrbloet en vas KerkwiJk bij de behandeling van de Staatsbegrooting voor 1871, om door middel van subsidiën de oprichting van zoodanige scholen te bevorderen, werd door den Minister bestreden en dientengevolge verworpen. De heer Tноввеске ging daarbij uit van het beginsel, dat eerst de school moest zijn tot stand gekomen, en dat alleen dan, wanneer het bleek dat zij Econ. 1877. 
zich niet staande kon houden zonder hulp van de Regeering, van een Rijks-subsidie sprake behoorde te zijn.

Onder den Minister GmerTsema kwam de zaak weder ter sprake; de Regeering zelve wenschte toen in beginsel uitgemaakt te zien, dat het Rijk subsidie zou kunnen toekennen, en hoewel er op dat oogenblik geen aanvragen bij de Regeering waren ingekomen, werd toch met dat doel éen pośt óp dè Staatsbegrooting voor 1873 uitgetrokken, die in de Tweede Kamer wel tegenspraak ondervond, maar niettemin met een zeer voldoende meerderheid werd goedgekeurd. Dit was weder eene aanmoediging voor hen, die zich vroeger de zaak hadden aangetrokken, maar bij gebrek aan geldelijke ondersteuning van Rijkswege haar hadden laten rusten. De school te Arnhem was réeds in 1871 geopend en hield zich sedert zonder Rijks-subsidie staande. Die te Rotterdam en Dordrecht waren in het begin van 1872 zonder subsidie in werking gebracht, die te Amsterdam, Deventer en Groningen bij het begin van den cursus 1872i73, eveneens zonder eenige ondersteuning van het Rijk.

Ook de heer Hebrskerk, die in 1874 weder optrad als Minister van Binnenlandsche Zaken, legde groote belangstelling in het middelbaar onderwijg voor meisjes aan den dag. Onder zijn eerste Ministerie was in 1867 het eerst eene som op de Staatsbegrooting gebracht ten behoeve van eene middelbare meisjesschool, nl. de Industrieschool voor vrouwelijke jeugd te Amsterdam; het is nog al opmerkelijk, dat toen door niemand eenige bedenking daartegen was gemaakt, zelfs niet door hen, die later het hardst tegen middelbare scholen voor meisjes ijverden en declameerden.

De heer Hezmskerk ging voort op den vroeger door hem ingeslagen weg; Leeuwarden verkreeg een subsidie van $f 5000$ 's jaars; dat voor Haarlem, dat onder den Minister Fock was verleend ten bedrage van $f 2000$, werd verhoogd tot $f 3500$; an Goes werd er een toegezegd van $f 5000$. Voor Dordrecht werd, met het oog op den geldelijken toestand dier gemeente, door de Regeering een subsidie onnoodig geacht; bij de behandeling der Staatsbegrooting voor 1876 verkreeg die gemeente nogtans bij amendement er een van $f 4000$ 's jaars. Aan eene in den Haag opterichten Industrieschool voor meisjes, waarvoor het eerste denkbeeld was uitgegaan van de Matschappij ter Bevordering van Nijverheid en het plan was ontworpen door eene commissie, waarvan onder meer ook de heeren HEEMSKerk en vaN DER Heim lid waren, werd eveneens een subsidie van $f 3000$ 's jaars toegezegd. In $1875 \mathrm{kwamen}$ de scholen te Leeuwarden en Utrecht, laatstgemelde zonder subsidie, in wer. 
king, en met het begin van den cursus $1876 / 77$ die ite Goes; roor weinige weken is ook de Haagsche Industrieschool geopend. Ip de Staatsbegrooting voor 1877 zijn nu ook subsidiën voorgesteld ten behoeve der scholen te Armhem en te Deventer; deze waren reeds vroeger door de gemeente-besturen aangevraagd, maar om gelijke redenen als aan Dordrecht geweigerd; nu er aan Dondrecht een was toegekend, eischte de billijkheid, dat Arnhem en Deventer, die meer dan Dordrecht er behoefte aan hadden, eveneens subsidie ontringen. De Tweede Kamer heeft die dezer dagen goedgekeurd.

Er zijn dus op dit oogenblik tien openbare middelbare scholen voor meisjes in werking; de beide Industriescholen te Amsterdam en te 's Gravenhage, hoewel eveneens tot de inrichtingen van M. o. behoorende, laat ik, als eenigszins van anderen aard en bestemming, thier verder buiten beschouwing. Vergelijkt men dit cijfer met dat van het getal hoogere :burgerseholen voor jongens, die in de eerste jaren na het in werking treden der wet in werking kwamen, dan is het wel niet zeer aanzienlijk, maar toch meen $i k$, dat wij reden hebben om te rreden te zijn, al missen wij in de lijst nog vele gemeenten, waar niet minder dan in de bovengenoemde behoefte aan middelbaar onderwijs voor meisjes bestaat. Is men in de eerste jaren na 1863 met de opening van nieuwe hoogere burgerscholen wel eens wat te vlug geweest en zag men zich daardoor in de keus van het onderwijzend personeel eenigszins beperkt, bij de meisjesscholen was zulks tot dus verre nog niet het geval, althans voor het :onderwijs in levende talen; voor aardrijkskunde en geschiedenis komt er zelfs thans reeds gebrek aan kandidaten, die examen voor middelbaar onderwijs helbben gedaan; wooral wanneer men onderwijzeressen voor meer dan één vak verlangt, is de keus nog uiterst ibeperkt en ziet men zioh verplicht zijn toevlucht te nemen tot bezitsters van de acte van hoofdonderwijzeres, an welke de wet (art. 78) eenige bevoegdheid toekent.

Vraagt men., welke de redenen ;ijn, waarom niet meer middelbare scholen voor meisjes gesticht zijn, dan kunnen daarvoor verschillende worden opgegeven. In de eerste plaats de kosten; zelfs dan wanneer het Rijk een subsidie geeft, zijn die voor de gemeente nog aanzienlijk; , bij de onder mijn toezicht geplaatste scholen is als regel angenomen, dat het Rijks-subsidie ongeveer evenveel bedraagt als de netto-uitgaven, die na aftrek van subsidie en opbrengst van schoolgelden ten laste der gemeente blijven. De gerneenten getroosten zich voor de middelbare jongensscholen 
reeds aanzienlijke uitgaven; die voor het lager onderwijs zijn in de laatste jaren aanzienlijk toegenomen; al wordt dan ook de behoefte aan eene middelbare meisjesschool gevoeld, men ziet dikwijls geen kans de daarvoor noodige gelden te vinden; dat was althans uitdrukkelijk het geval in een paar gemeenten, over welke mijn toezicht zich uitstrekt. Men tracht dan langs een goedkooperen, al is het dan ook minder goeden weg, het doel te bereiken en sticht of houdt scholen van meer uitgebreid lager onderwijs voor meisjes van 12 tot 17 jaren in stand, die van de middelbare niet zoozeer in doel versehillen, als wel in de middelen, waardoor men het tracht te bereiken, en in bekwaamheid van het onderwijzend personeel. Op andere plaatsen is men bevreesd door oprichting van een goed georganiseerde middelbare school de bestaande bijzondere inrichtingen te benadeelen; dit was vooral te 's Gravenhage het geval. In enkele meent men de kwestie te kunnen oplossen door aan de meisjes den toegang tot de jongens-hoogere-burgerschool te vergunnen. Eindelijk mag ook de strijd, dien sommigen tegen de middelbare scholen voor meisjes voeren, niet buiten rekening worden gelaten; van de argumenten van hen, die bevreesd zijn on aan de vrouw meer kennis en daardoor meer onafhankelijkheid in haar oordeel te geven, zijn zelfs in de Tweede Kamer der Staten-Generaal vermakelijke proeven geleverd; op huu standpunt hebben die tegenstanders misschien geen ongelijk, hoewel het niet onwaarschijnlijk is dat zij, wanneer zij eens meer van nabij kennis maakten met het onderwijs, dat op die scholen gegeven wordt, wel van meening zouden veranderen.

Er zijn echter ook andere bestrijders, namelijk zij die beweren, dat men nog geen stelsel voor de middelbare meisjesscholen heeft, en weer anderen, die trachten te bewijzen, dat het aangenomen stelsel niet deugt. Dat die eerste bewering geheel op onkunde rust, zal worden toegegeven door iedereen, die maar eenigszins, zij het ook alleen door de programma's, met de thans bestaande inrichtingen bekend is; die van vijfjarigen cursus toch komen, behoudens kleine wijzigingen, overeen met het door mij in 1870 gegeven programma, on die van driejarigen cursus trachten zooveel mogelijk hetzelfde te geven, als de drie hoogste klassen der scholen van vijfjarigen cursus. Die beschuldiging wordt dan ook weerlegd door hen, die het stelsel meenen te moeten bestrijden en dus wel degelijk het bestaan daarvan erkennen; in hoeverre hunne beoordeeling juist is en hunne argumenten steek houden, zal later blijken, als ik meer in 't bijzonder de inrichting van die scholen hoop ter sprake te 
brengen; gezegden, zoo als ik ergens aantrof, „dat de middelbare scholen zijn niets dan wat verbeterde kostscholen", zijn wel geen wederlegging waard. De hoofdstrijd is daarin gelegen, dat men de middelbare school wil dienstbaar maken om de meisjes te maken tot goede huishoudsters, moeders, opvoedsters en ik weet al niet wat nog meer; Multapatior, Constant en andere pseudonymen zijn de woordvoeders van die partij; zelfs schijnt de Redactie van " de Tijdspiegel" zich eenigszins aan die richting te willen aansluiten, zooals kan worden afgeleid uit een opstel, in de aflevering van September jl. voorkomende onder den titel: " de hervorming van de middelbare meisjesschool." Had de anonyme schrijver van die reclame voor de Arnhemsche school zich eenvoudig bepaald tot eene eerlijke en fatsoenlijke bestrijding der beginselen, tot dus verre bij de meisjesscholen in toepassing gebracht, men zou trachten òf zijne argumenten te weerleggen, òf zijn raad op te volgen; maar nu men daarin niets vindt dan onjuiste voorstellingen, zoowel van den tegenwoordigen toestand als van de veranderingen, die door de Arnhemsche autoriteiten in het tot dusver aangenomen stelsel heeten te zijn gemaakt, zal het wel het verstandigst zijn er zoo min mogelijk notitie van te nemen. Dr. V. Broinsma, leeraar aan de middelbare meisjesschool te Leeuwarden, is in het volgend nummer van ${ }_{n} \mathrm{de}$ Tijdspiegel" reeds tegen die "onjuistheden" opgekomen; de redactie, die het voor den anomymen berichtgever opneemt, tracht wel het vroeger beweerde voltehouden, maar ieder, die de verdediging heeft gelezen, zal moeten toestemmen, dat zij daarbij een vrij pover figuur maakt. Zij blijft volhouden, „dat alle middelbare scholen voor meisjes kwijnen, alleen Haarlem en Leeuwarden uitgezonderd; dat dit alleen daaraan is toe te schrijven, dat de Haarlemsche school gevoed wordt met de kweekelingen der Kweekschool voor onderwijzeressen, en dat Leeuwarden eene Directrice koos, die een goed bevolkte school medebracht." Voorts wordt beweerd, niet door redeneeringen bewezen, dat men tot dus verre overal en in alles op dit gebied heeft misgetast, maar dat men nu gelukkig te Aruhem den steen der wijzen heeft gevonden, die de tot dus verre gebrekkige, ja mislukte inrichting eensklaps tot een model voor alle andere zal maken!

Het ligt niet in mijne bedoeling over zoodanige beweringen met de heeren van ${ }$ de Tijdspiegel" te polemiseeren, evenmin als ik zulks heb gedaan, toen zij voor een jaar of wat voor den dag kwamen met hun programma met 27 leervakken en niet minder dan 35 tot 37 lesuren per week in elke klasse, welk plan hun 
misschien nu nog roor den geest gezweefd heeft, toen zij de nieuwe regeling prezen; is het laatste het geval, dan zon men inderdaad op een merkwaardige bekeering mogen wijzen. Evenmin zal ik mij wagen aan eene beoordeeling van de Arnhemsche school, welke ik niet anders ken dan door de gedrukte programma's; het voorbeeld van hen, die eene kritiek durven uitoefenen over inrichtingen, die zij nooit bezocht hebben, - eene trouwens in den tegenwoordigen tijd zeer algemeene kwaal, - werkt zoo afschrikkend op mij, dat ik mij op dat terrein niet durf begeven.

Ik zal mij derhalve bepalen tot eene mededeeling van den tegenwoordigen toestand der bestaande scholen, zoowel wat het getal van hare leerlingen betreft, als wat de inrichting aangaat van het onderwijs; van zelf zal dan blijken, of er reden is om van ${ }_{n} \mathrm{kwij}-$ ning" te spreken; tevens zal zich dan de gelegenheid voordoen om in eenige bijzonderheden te treden aangaande den aard en den omvang van het onderwijs, waarbij dan ook enkelo bedenkingen kunnen ter sprake komen, welke in den laatsten tijd daartegen zijn ingebracht, onder andere in eenige lezingswaardige opstellen, voor korten tijd door Dr. Bruingma in "het Schoolblad" geplaatst en waarin hoofdzakelijk wordt gehandeld over het onderwijs in de natuurkundige en daarmede verwante wetenschappen aan de meisjesschool.

De volgende tabel bevat een overzicht van het getal der leerlingen aan elke der bovengenoemde scholen, van hare oprichting af; zij zijn daarin geplaatst in dezelfde volgorde, waarin zij zijn tot stand gekomen.

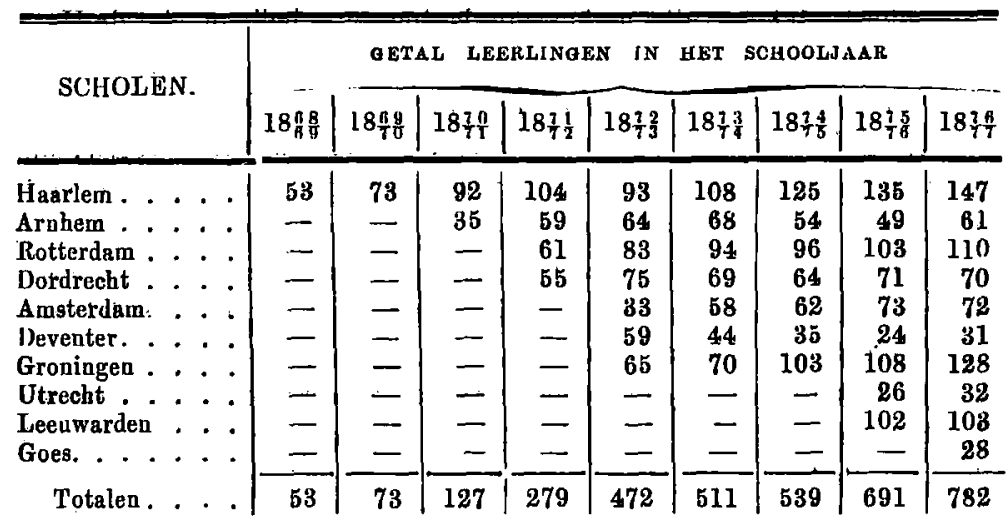

Hierbij moet in de eerste plaats in aanmerking worden genomen, 
dat de scholen te Haarlem, Arnhem, Rotterdam, Dordrecht, Groningen en Leeuwarden van een vijfjarigen cursus zijn, tot welken de. meisjes in den regel op 12 à 13 jarigen leeftijd worden toegelaten; dat die te Amsterdam, Deventer en Utrécht slechts een driejarigen cursus hebben, ongeveer gelijk staande met de drie hoogste klassen der volledige school van vijfjarigen cursus en derhalve bestemd voor meisjes van 14 à 15 tot 18 jaren; dat eindelijk de eerst onlangs te Goes geopende school nog slechts drie klassen telt, mạar bestemd is om van oen vierjarigen cursus to zijn; daar evenwel voor de toelating tot de laagste klasse geen kẹnis der fransche taal gevorderd wordt, schijnt de laagste klasse, in vergelijking met andere middelbare scholen voor meisjes, wel als eene p.oorbereidende afdeeling beschouwd te kunnen worden.

Is er nu bij de meeste dier scholen .kwijning te bespeuren, „kwijning tat op dezen dag", zelfs als men het laatste jaar 1876/77 buiten aanmerking laat, daar het opstel in "de Tijdspiegel" reeds in Augustus werd geschreven? De school te Haarlem is steeds vopruitgegaan; wel is waar vinden wij in 1872 een kleine vermindering van het getal leerlingen, namelijk van 104 tot 93 , maar in het volgend jaar werd dit verlies weder ruim ingehaald en sedert is het getal steeds vooruitgegaan. Bij het begin van den voorgaanden eursus zijn dan ook reeds maatregelen genomen tot splitsing van sommige klassen in parallel-afdeelingen. In hoeverre de te Haarlẹm gevestigde Kweekschool voor onderwijzeressen op den bloei der middelbare school invloed uitoefent, kan daaruit blijken, dat er op dit oogenblik onder de 147 leerlingen der school 14 (zegge:

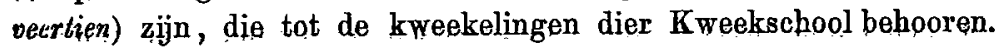
Zonder de Kweeksohool zou de school dus nog 133 leerlingen tellen.

Rotterdam zag in de puim vijf jaren, ședert de opening der school verloopen, het getal der leerlingen nagenoeg verdubbelen; ook daar was reeds splitsing van een paar klassen in parallel-afdeelingen noodig. Het getal der leerlingen is, in vergelijjing met Haarlem, nog niet groot, maar daar het steeds is toegenomen, kan van kwijnen geen sprake zijn. Te Dordrecht is het getal in de laatste jaren stationair gebleven; te Groningen is het van jaar tot jaar toegenomen; daar zijn de beide laagste klassen ook reeds elke in twee afdeelingen gesplitst. Te Leeuwarden bestaat de school nog te kort om een oordeel te kunnen yellen; dat het eijfer voor dit schooljaan niet honger is dan het voorgaande, is eenvoudig daaraan toe te sekrijven, dat bij de opening in 1875 tijdelijk een lagere afdeeling bij de laagste klasse werd gevoegd, ten einde een 25 tal leer- 
lingen van 11 à 12 jarigen leeftijd, welke de openhare school van meer uitgebreid lager onderwijs bezochten, die werd opgeheven toen de middelbare werd geopend, niet te dwingen nog voor één jaar naar eene andere school te gaan. Thans is die voorbereidende afdeeling opgeheven en bestaat de school uit haar normaal getal van vijf klassen, van welke de laagste ook reeds in twee parallel-afdeelingen is moeten gesplitst worden. Het is waar, dat de meeste leerlingen, die terstond na de opening de school bezochten, tot dus verre de opgeheven school voor m. u. l. o. hadden bezocht; maar dat zal wel overal het geval geweest zijn, waar de middelbare school in de plaats van eene al te hoog opgevoerde lagere kwam. Bovendien zijn hij het begin van den thans aangevangen cursus in 't geheel weder 19 nieuwe leerlingen toegelaten.

De eenige school van vijfjarigen cursus, die in getal leerlingen eer achteruit dan vooruit is gegaan, is de Arnhemsche, welker bevolking van 68 in 1873 daalde tot 49 in 1875; thans is het cijfer weder tot 61 gerezen.

Berekent men voor de scholen van vijfjarigen cursus de verhouding tusschen het bevolkingscijfer der gemeente en het getal leerlingen, dan vindt men voor het schooljaar 1876/77 voor Haarlem 44, Leeuwarden 38, Groningen 32, Dordrecht 27, Arnhem 17 en Rotterdam 9 leerlingen op elke 10000 inwoners. De beide laatstgenoemde zijn dus aanzienlijk lager; wat Rotterdam betreft, moet men niet uit het oog verliezen, dat in zulke groote gemeenten de concurrentie met de talrijke bijzondere scholen altijd nadeelig werkt.

Eene vergelijking van het getal leerlingen der scholen van driejarigen cursus met dat van de uitgebreidere inrichtingen is, uit hoofde van het verschillend karakter en den verschillenden omvang dier scholen, uiterst moeilijk; het verhoudingscijfer tot de bevolking bedraagt voor Deventer 17, voor Utrecht 7, voor Amsterdam slechts 2,5 ; daarbij is evenwel niet uit het oog te verliezen, dat de school te Utrecht eerst in 1875 geopend is. Mag men uit de cijfers eenige gevolgtrekking maken, dan zal die niet ten voordeele van de scholen van driejarigen cursus uitvallen en zouden dus de bedenkingen, die ik van het begin af aan tegen dat stelsel heb ingebracht, thans blijken niet ongegrond te zijn. Wat Amsterdam betreft, het is bekend, dat op het gebied van het onderwijs nieuwe insteilingen, hoe voortreffelijk ook ingericht, in den regel een geruimen tijd noodig hebben eer zij op de volle sympathie der bevolking kunnen rekenen; dat is ook bij de h. b. s. voor jongens gebleken, die thans eerst, na een meer dan tienjarig bestaan, 246 leerlingen 
telt; bovendien is daar, op 't gebied van onderwijs aan meisjes, de concurrentie sterker dan ergens anders. Nogtans is het getal der leerlingen van 33 tot 72 geklommen, en hoewel dat cijfer in het laatste jaar niet is toegenomen, kan ik toch volstrekt niet toestemmen, dat de Amsterdamsche meisjesschool kwijnt. Deventer daarentegen, dat in 1872 met 59 leerlingen opende, is sterk achteruitgegaan, daar dit cijfer in 1875 tot 24 daalde en nu niet meer dan 31 bedraagt. Wat eindelijk Goes betreft, daarvan is natuurlijk nog weinig te zeggen, behalve dat het cijfer zelfs nu reeds, in vergelijking met het bevolkingscijfer, vrij aanzienlijk mag worden genoemd.

Berekent men voor de laatste vijf jaren het gemiddeld getal leerlingen per school, dan vindt men de cijfers $67,73,77,77$ en 78 ; voor de scholen van vijfjarigen cursus bedragen deze eijfers zelfs $76,82,86,95$ en 103 . Neentt men daarbij in aanmerking, dat de school te Arnhem in die jaren eer is achteruit dan vooruit gegaan, dan blijkt ook uit deze cijfers, dat op een aanmerkelijken vooruitgang in plaats van op kwijning kan worden gewezen.

De verdeeling van de leerlingen over de verschillende klassen is voor den tegenwoordigen cursus $1876 / 77$ in de volgende tabel aangewezen. Ik heb daarin de scholen van vijfjarigen cursus in de eerste plaats vermeld; daarna die te Goes, die van een vierjarigen cursus zal zijn, doch, zoo als hiervóór reeds is opgemerkt, uit hoofde van de geringe eischen bij de toelating tot de laagste klasse wel niet veel hooger zal gaan dan de drie laagste klassen der volledige inrichtingen; eindelijk de drie scholen van driejarigen cursus, waaraan, om zoo te zeggen, de beide laagste klassen der volledige inrichtingen ontbreken.

\begin{tabular}{|c|c|c|c|c|c|c|c|c|}
\hline \multirow{2}{*}{ SCHOIEN. } & \multicolumn{6}{|c|}{ Getal leerlingen voor volledig onderwijs. } & \multirow{2}{*}{$\left|\begin{array}{c}\text { Geial der } \\
\text { leerlingen } \\
\text { voor en- } \\
\text { kele lessea }\end{array}\right|$} & \multirow{2}{*}{$\begin{array}{l}\text { Algemeen } \\
\text { rotaAL. }\end{array}$} \\
\hline & $\underset{\text { klasse. }}{\mathbf{1}_{\mathbf{6}}}$ & $\begin{array}{c}2{ }_{e} \\
\text { klisse. }\end{array}$ & $\begin{array}{c}3 \mathbf{c} \\
\text { klissset. }\end{array}$ & $\begin{array}{c}40 \\
\text { hlasse. }\end{array}$ & $\begin{array}{c}5_{\mathrm{e}} \\
\text { klasse. }\end{array}$ & Tolaal. & & \\
\hline Haarlem. & 36 & 36 & 46 & 19 & 10 & 147 & - & 147 \\
\hline Arnhem. & 18 & 12 & 15 & 8 & 4 & 57 & 4 & 61 \\
\hline Rotterdam. & 34 & 28 & 23 & 13 & 12 & 110 & - & 110 \\
\hline Dordrecht . & 14 & 12 & 14 & 12 & 9 & 61 & 9 & 70 \\
\hline Grouingen. & 56 & 30 & 14 & 6 & 4 & 110 & 18 & 128 \\
\hline Leeuwarden. & 47 & 24 & 17 & 8 & 3 & 99 & 4 & 103 \\
\hline Goes. . . . & 15 & 5 & 2 & $"$ & - & 22 & 6 & 28 \\
\hline A msterdam. & - & - & 28 & 20 & 18 & 66 & 6 & 72 \\
\hline Deventer. . & 一 & 一 & 16 & 4 & 6 & 26 & 5 & 31 \\
\hline Utrecht . & & - & 11 & 17 & 4 & 32 & - & 32 \\
\hline 'Totalen & 220 & 147 & 186 & 107 & 70 & 730 & 52 & 782 \\
\hline
\end{tabular}


Aan de scholen te Haarlem, Rotterdam en Utrecht worden geen leerlingen voor enkele lessen toegelaten; aan de andere is het getal zeer uiteenloopend; vooral te Groningen is het aanzienlijk; het is daar meer een verzuimen van sommige lessen, die minder in den smaak vallen, dan het bijwonen van enkele lessen in de hoogere klassen door enkele leerlingen; zelfs gebeurde het enkele malen, dat leerlingen midden in den cursus ophielden de lessen in een of ander vak bij te wonen, als dit vak (of de leeraar of onderwijzeres) minder in den smaak van de leerlingen viel. Toch is ook daar reeds eenige vooruitgang merkbaar; in 1874 waren van de 103 leerlingen 25 ingeschreven voor enkele lessen, in 187521 van de 108 (van deze behoorden 12 tot de beide laagste klassen) en nu slechts 18 van de 128. Ik heb getraoht te bewerken, dat althans in de twee laagste klassen geen andere leerlingen dan voor volledig onderwijs zouden worden toegelaten, maar het gemeentebestuur achtte dit nịet wenschelijk; alleen heeft men bepaald, dat althans in den loop van het jaar geen verandering of weglating van vakken zal worden toegelaten; het zal mij verheugen, indien zonder dwangmiddelen het doel, al is het dan ook langzamerhand, kan worden bereikt. Ook bij alle scholen te zamen is in dit opzicht vooruitgang te merken; terwijl in $1873 \mathrm{nog} 11$ en in 187410 , ten honderd der leerlingen slechts een gedeelte der lessen bijwoonden, was dit de beide laatste jaren slechts met ongeveer 6,5 ten honderd het geval. Welke vakken het meest verzuimd worden, kan uit de volgende opgaaf over 1875 blijken (die over $1876 \mathrm{kan}$ ik nog niet geven). Van de 44 zoogenaamde "toehoorderessen" woonden 41 geen lessen bij in rekenen of wiskunde, 33 niet in natuurkundige wetenschappen, 34 niet in aardrijkskunde en geschiedenis, 20 niet in Nederlandsch, 8 niet in Franseh, 6 niet in Duitsch, 13 niet in Engelsch, 17 niet in het teekenen. Het verzuim was dus voor de talen verreweg het minste, het grootste voor wiskunde, rekenen daaronder begrepen; wel een bewijs dat hierbij meer op het aangename dan op het nuttige wordt gelet.

Nogtans moet hier worden opgemerkt, dat het bezoek van enkele lessen bij alle middelbare scholen voor meisjes te zamen geringer is dan aan de hoogere burgerscholen voor jongens, aan welke in 1875 nog 10 ten honderd der leerlingen slechts een gedeelte der lessen volgden, terwijl het in de beide voorafgaande jaren nog 12,5 en 11,6 ten honderd had bedragen.

Men heeft de opmerking gemaakt, dat de middelbare scholen voor meisjes veel minder bezocht zijn dan die voor jongens. Het spreekt van zelf, dat eene vergelijking alleen mogelijk is voor scholen 
in dezelfde gemeente en van denzelfden omvang; de scholen van drie of vierjarigen cnrsus te Amsterdam, Utreeht, Goes en Deventer moeten derhalve buiten beschouwing blijven. Van de zes andere gemeenten zijn de cijfers bij den aanvang van den cursus 1876/77 aangewezen in het volgende overzicht.

\begin{tabular}{l|c|c}
\hline \hline G EMEENT kN. & $\begin{array}{c}\text { Getal leerlingen } \\
\text { op de middelbare } \\
\text { meisjesschool. }\end{array}$ & $\begin{array}{c}\text { Getal leerlingen } \\
\text { op de jungens } \\
\text { H. B. S. }\end{array}$ \\
\hline Arnhem . . . . . & $6 \mathrm{~L}$ & 102 \\
Rotterdain . . . . & 110 & 226 \\
Dordrecht. . . . . & 70 & 144 \\
Haarlem...... & 147 & 200 \\
Leeuwarden. . . . . & 103 & 117 \\
Groningen . . . . & 128 & 150 \\
\hline Total. . . . & 619 & 939
\end{tabular}

Hierbij valt evenwel op te merken, dat in de laatste kolom voor Rotterdam en Haarlem het totaal genomen is van het getal leerlingen aan beide jongensscholen, nl. de $\mathbf{h}$. b, s. van 5jarigen cursus en die van 3jarigen cursus; laat men de laatstgenoemde achterwege, dan zouden die eijfers, in plaats van 226 en 200, slechts 156 en 126 bedragen.

De tabel doet ons zien, dat inderdaad het getal der vrouwelijke leerlingen der middelbare school in bovengemelde zes gemeenten te zamen zich tot dat der mannelijke verhoudt als 2 tot 3; de verhouding is ongunstig in Rotterdam en Dordrecht, daarentegen gunstig in Leeuwarden en Groningen. Intusschen zijn er verschillende redenen voor dit verschil aan te wijzen. Een der voornaamste is zeker daarin gelegen, dat het nut van een degelijk onderwijs voor jongens veel meer wordt ingezien dan voor meisjes; jongens, dat weet men, - moeten veel leeren om door de wereld te komen; voor meisjes zien velen daarvan nog de noodzakelijkheid niet in; de meer gegoede klasse, die dikwijls aan het aanleeren van $n$ gedistingeerde manieren" meer waarde hecht dan aan het opdoen van degelijke kennis, geeft veelal de voorkeur aan de kostschool; de moeders uit de burgerklasse zien de noodzakelijkheid niet in om hare dochters meer te doen leeren dan zij zelve geleerd hebben; $\left(^{*}\right)$

(*) In den regel vindt de middelbare school ook bij de gegoede klasse meer sympathie bij de vaders dan bij de moeders. Ik zou voorbeelden kunnen bijbrengen, waaruit duidelijk blijkt, dat de vader liever zijne dochter naar de middelbare school zou hẹbben gezonden, maar teu slotte moest toegeven aan den wẹsch 
zij houden haar dus liever na het $12 \mathrm{e}$ of $13 \mathrm{e}$ jaar thuis, om ze daarna alleen nog een school voor handwerken te laten bezoeken. Gaan reeds een paar jongens op de middelbare school, wier schoolgeld met inbegrip van boeken en schoolbehoeften een heele post op het budget bedraagt, dan kan men niet besluiten, ook voor elke der dochters nog weer eens eene som van vijftig guldens en de kosten van boeken enz. te betalen. Eindelijk moet niet uit het oog worden verloren, dat zij, die uit godsdienstige beginselen tegen het middelbaar onderwijs zijn, tegen de meisjesschool veel heftiger strijd voeren dan tegen de jongensschool; van de laatste wordt door hen menigmaal gebruik gemaakt als van een noodzakelijk kwaad, opdat de jongelieden in kennis althans niet achter zouden staan bij anderen; maar voor meisjes kan men daar vooreerst nog wel buiten. Ik durf mij niet vleijen, dat in deze beschouwingen spoedig veel verandering zal komen, en verwacht dus, dat in de meeste gemeenten de middelbare meisjesschool nog wel bij de jongensschool zal blijven achterstaan.

Het onderwijzend personeel an de bovengenoemde tien scholen bestaat thans uit 64 onderwijzeressen en 51 leeraren, van welke laatsten 34 tevens werkzaam zijn aan eene andere inrichting van middelbaar onderwijs in de gemeente. Van de 10 Directrices onderwijzen er 2 Nederlandsch, 2 geschiedenis, 2 Fransch, 2 Hoogduitsch en 2 Engelsch. Van de 64 onderwijzeressen geven er 50 onderwijs krachtens acten, onder de wet van 1863 verkregen, namelijk 9 in nederlandsche taal- en letterkunde, 10 in fransche taal- en letterkunde, 11 in hoogduitsche taal- en letterkunde, 9 in engelsche taalen letterkunde, 5 in geschiedenis of aardrijkskunde of in beide deze vakken, 1 in wiskunde, 1 in natuurlijke historie, 2 in teekenen en 2 in gymnastiek; een negental van deze geven bovendien nog onderwijs in Nederlandsch, geschiedenis of aardrijkskunde krachtens eene acte als hoofdonderwijzeres; voor het onderwijs in deze drio laatstgenoemde vakken zijn bovendien nog 6 werkzaam zonder andere acte, die voor middelbaar onderwijs in die vakken bevoegdheid geeft, dan die van hoofdonderwijzeres; voorts ééne onderwijzeres in Engelsch krachtens eene acte volgens art. 72 der wet van 1857, en eindelijk 6 onderwijzeressen in handwerken en ééne in zang. Van de leeraren zijn 27 met den graad van doctor of candidaat,

van Mama, die het meisje liever naar een hoogstfatsoenlijke kostschool wilde zenden. Het gebeurt zelfs wel eens, dat meisjes vroeger van de middelbare school worden afgeuomen, alleen om nog eenigen $1 \mathrm{ijd}$ op eene kostschool tc kunneu doorbrengen. 
16 met eene acte volgens de wet van 1863,3 met eene oude acte en 5 zonder graad of acte. Van deze 51 leeraren geven 7 onderwijs in wiskunde, 2 in wis- en natuurkundige wetenschappen in haar geheelen omvang, 12 in een of meer onderdeelen der natuurkundige wetenschappen, 2 in gezondheidsleer, 2 in aardrijkskunde, 1 in geschiedenis , 8 in staatsinrichting of staathuishoudkunde, 8 in teekenen, 2 in aesthetica, 5 in gymmastiek en 2 in het zingen.

Uit-het voorgaande blijkt, dat men tot dusverre zich steeds gehouden heeft aan het ook door mij indertijd op den voorgrond gestelde beginsel, dat geen Directeur, maar eene Directrice aan het hoofd behoort te staan; voor zooveel mij bekend is, heeft men op geen der bovengemelde tien plaatsen berouw, zoodanig besluit te hebben genomen. Zelfs in Arnhem, waar aanvankelijk de Directeur der hoogere burgerschool tot mede-directeur der meisjesschool was benoemd, en deze later, toen hij tot Hoogleeraar te Leiden was benoemd, door den Directeur der Kweekschool voor onderwijzeressen werd vervangen, heeft men dit stelsel verlaten en, na het aan laatstgenoemde verleende eervol ontslag, de betrekking van mede-directeur afgeschaft.

Het getal van de mannelijke en vrouwelijke onderwijzers is bij de verschillende scholen nog al uiteenloopend; Haarlem heeft 7 vrouwelijke en 5 mannelijke, Arnhem 7 v. en $7 \mathrm{~m}$., Rotterdam 9 v. en $5 \mathrm{~m}$. (binnenkort komt hier nog eene vrouwelijke bij), Dordrecht 6 v. en $5 \mathrm{~m}$., Groningen 7 v. en $7 \mathrm{~m}$., Leeuwarden $10 \mathrm{v}$. en $3 \mathrm{~m}$, Goes 5 v. en $3 \mathrm{~m}$., Amsterdam 6 v. en $4 \mathrm{~m}$., Deventer 3 v. en $6 \mathrm{~m}$. en Utrecht $4 \mathrm{v}$. en $6 \mathrm{~m}$. Daarentegen is er, zooals reeds uit het voorgaande kan blijken, weinig onderscheid in de vakken, die aan mannelijke of vrouwelijke docenten an de onderscheidene scholen zijn opgedragen. Voor het onderwijs in de moedertaal en de drie vreemde talen treft men uitsluitend onderwijzeressen aan; evenzoo voor geschiedenis en aardrijkskunde, behalve te Deventer, waar het onderwijs in aardrijkskunde tijdelijk aan een leeraar der hoogere burgerschool is opgedragen, en te Utrecht, waar een gedeelte van het onderwijs in aardrijkskunde, alsmede dat in geschiedenis, door twee leeraren wordt gegeven. Voor staatsinrichting of staathuishoudkunde vindt men uitsluitend leeraren, behalve to Goes en te Utrecht, waar deze vakken niet op het programma voorkomen. Voor wis- en natuurkundige wetenschappen heeft men leeraren, op zeer enkele uitzonderingen na; to Leeuwarden is namelijk eene onderwijzeres, die met gunstigen uitslag examen voor M. 0 . in wiskunde en in boekhouden heeft gedaan, met het geheele onderwijs in 
wiskande, rekenen en boekhouden daaronder begrepen, belast; te Haarlem en te Arnhem geeft eene derionderwijzeressen, krachtens eene acte als hoofdonderwijzeres, eenig onderwijs in rekenen; to Rotterdam is eene onderwijzeres, welke eene acte voor M. O. in de natuurlijke histerie heeft verkregen, met het onderwijs in planten dierkunde belast. Voor het teekenen zijn overal leeraren, behalve te Leeuwarden en te Amsterdam, waar dit onderwijs aan eene onderwijzeres met acte voor $\mathbf{M}$. 0 . is opgedragen; voor gymnastiek zijn conderwijzeressen te Arnhem en Rotterdam, leeraren te Haarlem, Goes., Leeuwarden, Deventer en Groningen; te Dordreoht, Amsterdam en Utrecht wordt igeen onderwijs in gymnastiek gegeven. Afzonderlijke leeraren in aesthetica of kunstgeschiedenis vindt imen te Amsterdam en te Rotterdam; aan de school te Bordrecht wordt hierin onderwijs gegeven door den leeraar in teekenen, te Utrecht door de Directrice en te Deventer door den leeraar, die tevens met onderwijs in staathuishoudkunde en gronden der staatsinrichting is belast. Te Arnhem en Leeuwarden zijjn afzonderlijke leeraren voor gezondheidsleer angesteld; aan de scholen te Arnhem en Groningen zijn leeraren, aan die te Leeuwarden is eene onderwijzeres voor den zang; aan de school te Haarlem wordt hierin door eene der onderwijzeressen onderwijs gegeven. Onderwijzeressen in handwerken zijn aan de scholen te Rotterdam, Dordrecht, Haarlem, Goes, Leeuwarden en Groningen; te Arnhem 'en IUtrecht wordt het onderwijs door eene of meer der gewone onderwijzeressen gegeven; te Amsterdam en te Deventer komt dit wak niet op het programma voor.

Uit het 'voorgaande is reeds eenigszins gebleken, dat de sprogramma's der onderscheidene scholen niet geheel dezelfde 'zijn.; nogtans is het verschil niet groot. Het zou en onnoodige :omslag zijn die hior in hun geheelen omvang op te nemen; ik bepaal mij dus tot een beknopt overzicht, waaruit mon kan nagaan, waarin hoofdzakelijk het verschil bestaat. Als uitgangspunt : zou 'daarbij kunnen dienen het programma, dat ik in 1870 heb gegeven (Eeonomist 1870 , bl. 23). Men zal zich herinneren dat ik dat als eene cerste proeve heb gegeven, waarover de ondervinding later uitspraak sou idoen; toen reeds vermoedde ik, dat wellicht een gedeelte van den itijd, roor de handwerken bestemd, beter aan teekenen kon worden besteed; de ondervinding heeft spoedig doen zien, dat dit vermbeden juist was. Nog enkele andere wijzigingen van ondergeschikt belang zou ik wenschen ingevoerd te zien, zoo als 
dan ook reeds aan sommige scholen is geschied. Geschiedenis behoort meer van de lagere klassen naar de hoogere te worden overgebracht, aardrijkskunde kan daarentegen meer in de lagere gegeven worden, mits wiskundige aardrijkskunde (of kosmographie of populaire sterrekunde) eerst in de beide hoogste behandeld wordt. Plant- en dierkunde kunnen in de hoogere klassen ingekrompen worden; met natuurkunde kan men in de 3e klasse beginnen, met scheikunde eerst in de $4 \mathrm{e}$; de ondervinding heeft mij geleerd, dat eene afzonderlijke behandeling dier vakken, mits in goed verband met elkander (hetgeen natuurlijk het best kan geschieden, als beide dobr denzelfden leeraar onderwezen worden), de voorkeur verdient boven een gelijktijdige, zoo als ik in mijn eerste opstel raadzaam achtte. Eenige versterking in de 5e klasse acht ik nuttig, opdat voor den leeraar tijd beschikbaar zij om eens een uitstapje te doen op het gebied der toepassingen, waarover straks náder. Wat de meisjes van boekhouden noodig hebben, kunnen zij wel in eene les per week in de 5e klasse leeren. Het onderwijs in staathuishoudkunde, dat, bij de verschillende richtingen op dat gebied, meer en meer moeilijk wordt, zou m. i. achterwege kunnen blijven en het beschikbare uur in de hoogste klasse alleen besteed kunnen worden om een overzicht van de inrichting van den Nederlandsohen Staat te geven. Het onderwijs in teekenen heb ik van 2 tot 3 uur per klasse gebracht; in de beide hoogste kan daarvan één uur 's weeks afgenomen worden voor aesthetica of kunstgeschiedenis, indien men ten minste gelegenheid heeft daarvoor een geschikten leeraar te vinden. Voor handwerken heb ik in elke klasse slechts 2 uren beschikbaar gesteld, vooral ook om het getal lesuren per week niet boven 30 te brengen; te Rotterdam heeft men daarvoor ook slechts 10 uur per week bestemd en de ondervinding heeft geleerd, dat zulks voldoende is. De zanglessen heb ik niet onder de gewone lessen opgenomen; er zijn onder de leerlingen vele, die of geen gehoor hebben òf voor wier gezondheid het zingen hetzij tijdelijk, hetzij altijd nadeelig is; deze kunnen dus die lessen niet bijwonen; men moet haar dan onder de zangles aan zich zelve overlaten of mèt wat anders bezighouden. Daarom verdient het te Groningen ingevoerde stelsel aanbeveling, waar het onderwijs in zang facul. tatief is en op vrije middagen wordt gegeven; dientengevolge maken van die lessen alleen die meisjes gebruik, die muzikaal gehoor en anleg hebben, en zijn derhalve de vorderingen ook beter.

Ik laat nu hier in de eerste plaats mijn gewijzigd programma volgen. 


\begin{tabular}{|c|c|c|c|c|c|c|}
\hline \multirow[b]{2}{*}{ LEER VAKKEN. } & \multicolumn{5}{|c|}{ Getal lesuren 's weeks in de } & \multirow[b]{2}{*}{ Totaal. } \\
\hline & $\underset{\substack{1 \mathbf{e} \\
\text { klasse. }}}{.}$ & $\begin{array}{c}2 \mathrm{e} \\
\text { klasse. }\end{array}$ & $\begin{array}{c}3^{e} \\
\text { klasse. }\end{array}$ & $\begin{array}{c}4 \mathrm{e} \\
\text { klasse. }\end{array}$ & $\begin{array}{c}5 \mathrm{e} \\
\text { klasse. }\end{array}$ & \\
\hline 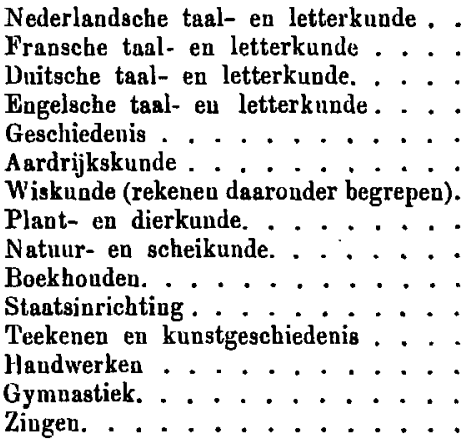 & $\begin{array}{l}4 \\
4 \\
4 \\
2 \\
2 \\
3 \\
4 \\
2 \\
" \\
" \\
" \\
3 \\
2 \\
2 \\
\text { op de }\end{array}$ & $\begin{array}{c}3 \\
3 \\
3 \\
4 \\
2 \\
3 \\
3 \\
2 \\
" \\
" \\
" \\
3 \\
2 \\
2 \\
\text { vrije }\end{array}$ & $\begin{array}{c}3 \\
3 \\
3 \\
3 \\
3 \\
2 \\
3 \\
1 \\
2 \\
2 \\
3 \\
2 \\
2 \\
2 \\
\text { mid }\end{array}$ & $\begin{array}{c}3 \\
3 \\
3 \\
3 \\
3 \\
2 \\
2 \\
1 \\
3 \\
n \\
. \\
3 \\
2 \\
2 \\
\text { dagen }\end{array}$ & $\begin{array}{l}3 \\
3 \\
3 \\
3 \\
3 \\
1 \\
2 \\
1 \\
4 \\
1 \\
1 \\
3 \\
2 \\
*\end{array}$ & $\begin{array}{r}16 \\
16 \\
16 \\
13 \\
13 \\
11 \\
14 \\
7 \\
9 \\
1 \\
1 \\
15 \\
10 \\
8\end{array}$ \\
\hline Totaal . . . . & 30 & 30 & 30 & 30 & 30 & 150 \\
\hline
\end{tabular}

De volgende tabel geeft een overzicht van de programma's van alle scholen van vijfjarigen cursus, benevens mijn programma van 1870 en het hierboven gegevene; voor Arnhem geef ik, met het oog op de onlangs daar ingevoerde "hervorming", zoowel het oude als het nieuwe programma.

\begin{tabular}{|c|c|c|c|c|c|c|c|c|c|}
\hline \multirow{2}{*}{ LEERV AKKEN. } & \multicolumn{9}{|c|}{$\begin{array}{c}\text { Getal lesuren per week in alle vijf klassen } \\
\text { volgens programma }\end{array}$} \\
\hline & $\left|\begin{array}{l}i \underset{\infty}{\infty} \\
\dot{\infty} \rightarrow-1\end{array}\right|$ & $\left|\begin{array}{l}\infty \\
\infty \\
\infty \\
\infty\end{array}\right|$ & 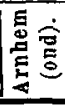 & 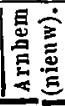 & 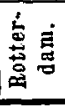 & 岁蓄 & 宠 & 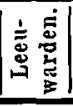 & 点 \\
\hline Nederlandsche taal en letterk. & 16 & 16 & 14 & 16 & 16 & 15 & 20 & 14 & 15 \\
\hline Fransche & 16 & 16 & 16 & 13 & 16 & 18 & 17 & 17 & 17 \\
\hline 1)uitsche & 16 & 16 & 16 & 13 & 16 & 16 & 16 & 17 & 18 \\
\hline Eugelsche & 13 & 13 & 15 & 13 & 13 & 14 & 16 & 12 & 14 \\
\hline Geschiedenis . & 13 & 13 & 15 & 13 & 13 & 12 & 10 & 12 & 15 \\
\hline Aardrijkskunde . & 10 & 11 & 10 & 10 & 10 & 8 & 10 & 10 & 12 \\
\hline Wiskunde . . . . . & 14 & 14 & 16 & 14 & 15 & 17 & 12 & 17 & 15 \\
\hline Plant- eu dierkunde. . & 9 & 7 & 5 & 3 & 9 & 7 & 6 & 10 & 8 \\
\hline Natunr en scbeikunde. & 7 & 9 & 9 & 6 & 8 & 8 & 8 & 10 & 10 \\
\hline Boekbouden . . . . . & 2 & 1 & 1 & $"$ & 1 & 2 & 2 & 1 & $"$ \\
\hline Staatsinrichting of staathuish. & 1 & 1 & 2 & 1 & 1 & 1 & 1 & 1 & 2 \\
\hline $\begin{array}{l}\text { Teekenen. } \\
\text { Knnstgeschiedenis of aesthetiek }\end{array}$ & 10 & 15 & 10 & 9 & $\begin{array}{r}13 \\
2\end{array}$ & $\begin{array}{r}13 \\
2\end{array}$ & 10 & $\begin{array}{r}11 \\
\prime \prime\end{array}$ & 15 \\
\hline Handwerken . . . . . & 20 & 10 & 12 & 8 & 10 & 14 & 15 & 13 & $1^{2}$ \\
\hline Schrijuen. * : . & $"$ & $"$ & $"$ & $n$ & 2 & 2 & $"$ & 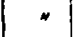 & $"$ \\
\hline Klassieke oudheid. & $"$ & " & 3 & " & " & $"$ & $"$ & " & $"$ \\
\hline Voedingsleer . . . & $"$ & $"$ & $"$ & 2 & $n$ & $"$ & $"$ & $"$ & $"$ \\
\hline Gezondheidsleer. . : & $"$ & $"$ & $"$ & 2 & $"$ & $"$ &. & 2 & $"$ \\
\hline Ziel- en opvoedkunde. & $"$ & $"$ & $"$ & 2 & - & $"$ & $"$ & $"$ & $"$ \\
\hline Zingen. : . . . . & 5 & p. m. & $\mathbf{5}$ & $\mathbf{5}$ & $"$ & $"$ & 1 & $\mathbf{5}$ & p. $\mathbf{m}$. \\
\hline Gymunstick . & $\mathbf{3}$ & 8 & $1^{10}$ & 11 & $\mathbf{5}$ & $"$ & (i) & 8 & 2 \\
\hline Dungen $\cdot \cdot \cdot \cdot \cdot \cdot \cdot \cdot \cdot$ & " & " & $"$ & 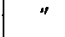 & $"$ & $"$ & $"$ & $"$ & $\mathbf{5}$ \\
\hline Totaal . . . . & 160 & 150 & 160 & 140 & 150 & 149 & 150 & 160 & 160 \\
\hline
\end{tabular}


In de eerste plaats blijkt hieruit, dat het verschil tusschen het vroegere programma te Arnhem en het thans ingevoerde niet zoo groot is, als het opstel in "de Tijdspiegel" zou doen verwachten. Het geheel getal lesuren is verminderd tot 28 's weeks voor elke klasse; in dit opzicht is men verder gegaan dan aan eenige andere school; deze inkrimping doet zich het meest gevoelen bij het onderwijs in vreemde talen, vooral bij dat in Fransch en Duitsch. Onder de tien uren, die hier als aardrijkskunde zijn opgegeven, komen er twee voor, die in het programma afzonderlijk als kosmographie vermeld zijn; eenvoudigheidshalve heb ik die bij de aardrijkskunde gevoegd, daar toch aan de andere scholen eveneens in de hoogere klassen hetzelfde plaats heeft. De natuurwetenschappen schijnen te Arnhem een vrij aanzienlijke vermindering te hebben ondergaan; doch hierbij is niet uit het oog te verliezen, dat in het oude programma de gezondheidsleer, waarvoor thans twee afzonderlijke uren zijn bestemd, bij de natuur- en scheikunde waren gevoegd, en dat bovendien thans eveneens twee uren zijn bestemd voor "scheikunde, toegepast op de gezondheidsleer." Daarentegen is $n u$ het boekhouden bij de rekenkunde gevoegd en komt de meetkunde voor onder den naam van "eigenschappen van figuren en lichamen;" ik heb echter deze onderdeelen in de tabel gemakshalve maar als wiskunde bijeengevoegd. Evenzoo zijn de gronden der staatsinrichting thans onder geschiedenis opgenomen. Aan teekenen wordt in de $5 \mathrm{e}$ klasse slechts één uur besteed, in handwerken wordt in die klasse in 't geheel geen onderwijs gegeven. Daarentegen treffen wij op het programma voor die klasse twee uren "ziel- en opvoedkunde" aan. De opname van dat vak maakt dan ook het eenige wezenlijke verschil uit tusschen het Arnhemsche programma en dat van de andere scholen, voor zoover de vakken betreft; wat den aan elk besteden tijd aangaat bepaalt het verschil zich tot een kleine inkrimping voor sommige vakken, in verband met de vermindering van het geheel getal lesuren, vooral voor de vreemde talen. Alleen moet er nog bepaald op gewezen worden, dat men te Arnhem in de lagere klassen in zekeren zin, dat is voor sommige vakken, het stelsel van klasseleeraars heeft ingevoerd, in plaats van vakleeraars; dientengevolge is eene der onderwijzeressen belast met nederlandsch, engelsch en handwerken, eene andere met hoogduitsch en handwerken, eene met fransch en ziel- en opvoedkunde, eene met nederlandsch, hoogduitsch en geschiedenis, en twee met nederlandsch, geschiedenis, aardrijkskunde, rekenkunde en handwerken. Aan andere scholen heeft licon. 1877. 
men dit niet zoover uitgestrekt, hoewel ook daar soms combinatie van vakken in dezelfde persoon wordt aangetroffen. Geschiedenis en aardrijkskunde zijn nagenoeg overal aan dezelfde opgedragen; te Haarlem is bovendien eene met Nederlandsch en aardrijkskunde, te Groningen eene met Duitsch en aardrijkskunde belast; te Rotterdam zal er eerlang eene benoemd worden voor Fransch en geschiedenis; aan de meeste scholen is slechts één leeraar voor de verschillende onderdeelen der natuurkundige wetenschappen; to Rotterdam, Dordrecht en Utrecht zijn afzonderlijke docenten voor natuurlijke historie, te Leeuwarden een afzonderlijke leeraar voor gezondheidsleer; te Arnhem zijn deze vakken over vier leeraren verdeeld.

De tijd zal moeten leeren, of de resultaten van het stelsel van klasse-leeraren, zooals het voor de lagere klassen te Arnhem is ingevoerd, zooveel beter zijn dan die van het stelsel van vakleeraren. Hoeveel men er ook tegen moge geredeneerd hebben, ook yoor de jongens-scholen, ik heb de nadeelige gevolgen van het laatstgenoemde stelsel nog nergens kunnen opmerken, mits slechts gezorgd wordt, dat de eenheid tusschen het onderwijs niet verbroken wordt en dat vooral niet elk leeraar, geheel zijn eigen weg gaande, de leerlingen overlaadt met huiswerk; deze gebreken kunnen echter gemakkelijk worden uit den weg geruimd door een degelijke zamenwerking van het onderwijzend personeel onder krachtige leiding van hem of haar, die aan het hoofd staat. Overal waar dit plaats heeft (en ik zou een menigte onder mijn toezicht geplaatste scholen, zoo voor meisjes als voor jongens, kunnen opnoemen, waar zulks inderdaad het geval is), heeft men geen reden om over minder goede gevolgen van dat stelsel te klagen; of het doelmatig is, de leerlingen gedurig van onderwijzeres te laten veranderen, zooals noodzakelijk het geval moet zijn, wanneer, zooals te Arnhem, dat in Nederlandsch en in handwerken verdeeld is tusschen vier, dat in geschiedenis, in aardrijkskunde en in rekenen tusschen drie personen, meen ik te moeten betwijfelen.

Wat verder de verdeeling der vakken over de verschillende klassen betreft, zoo moet ik, naar aanleiding van het bovenstaande, nog het volgende opmerken. De wensch is meermalen geuit, dat aan het onderwijs in moderne talen meer tijd zou worden besteed; mijns inziens is dit niet mogelijk, zoo men daaraan niet het onderwijs in andere vakken wil opofferen, of het wekelijksche getal lesuren vermeerderen. Dit laatste zal wel niemand wenschelijk achten; wanneer de leerlingen gemiddeld vijf 
uren per dag op school zijn, is het zeker genoeg, vooral wanneer men daarbij in aanmerking neemt, dat het huiswerk voor die der lagere klassen nog misschien een tweetal, voor de hoogere een drietal uron per dag kan eischen. $\left({ }^{*}\right)$ Onder de 150 uur van mijn programma zijn er 33 (teekenen, handwerken en gymnastiek), voor welke geen inspanning van den geest wordt gevorderd; men kan dus aannemen, dat van het gemiddeld getal van vijf lesuren per dag er één min of meer tot verpozing kan dienen, zoodat men niet kan zeggen dat, bij eene goede verdeeling van de werkzaamheden, dan nog te veel van den geest gevorderd wordt.

De voorstanders van uitbreiding van het onderwijs in vreemde talen verlangen deze hoofdzakelijk, opdat de leerlingen meer bedrevenheid zullen verkrijgen in het spreken. Zij maken zich echter illusiën, wanneer zịj meenen, dat langs dien weg dat doel kan worden bereikt. Op eene school met klassen van twintig en meer leerlingen, leert men geen drie vreemde talen - ik zeg niet eens zuiver - maar zelfs niet eens met gemak spreken; het is overdreven dit te eischen van meisjes van 17 à 18 jarigen leeftijd, die bovendien ook nog iets anders hebben te leeren gehad. Zij, die hierop zoo bijzonder gesteld zijn, doen daarom beter, zoo zij hunne dochters zenden naar kostscholen, hoogstens voor een twintigtal leerlingen bestemd en met een volledig stel vreemde secondantes, die den geheelen dag met de leerlingen omgaan en haar dwingen zich steeds in eene vreemde taal uit te drukken; is bovendien de opvoeding onder leiding van eene Fransche of Engelsche bonne voorafgegaan, dan is het wel mogelijk, dat de meisjes, als zij "in de wereld" komen, alleraardigst in twee of drie vreemde talen zullen weten te keuvelen; hoe het dan echter met de kennis van andere vakken gesteld is, zullen wij liefst maar niet onderzoeken. Over de taalkundige kennis bij de meisjes, die de middelbare school verlaten, valt trouwens niet te klagen, als men ten minste geen overdreven eischen stelt; hare kennis van de taalkunde is, ook praktisch, over 't algemeen zeer voldoende, en van de letterkundige producten hebben $z i j$ er genoeg leeren kennen om verder met lust zich ook met andere bekend te kunnen maken. Dat er enkele uitzonderingen 'zijn, misschien aan eene minder gelukkige keuze van personeel toe te schrijven, spreekt wel van zelf.

(*) Aan eukele sclıolen wordt voor het huiswerk meer tijd gevorderd; ik keil' dit echter nitdrıkkelijk af en stel den bier keuvemden tijd als een maximmm, dat voor meisjesscholen viet dan zelden behourt te "ur.Jen bes'ikit. 
Volgens de tabel wordt aan de meeste scholen minder tijd aan Engelsch besteed, dan aan andere vreemde talen; mijns inziens volkomen terecht. De engelsche taalregels zijn gemakkelijk; en daar alle paedagogen het eens zijn, dat het verkeerd is tegelijk met twee vreemde talen te beginnen, vangt men overal in de eerste klasse aan met Duitsch, in de tweede met Engelsch. Alleen Haarlem maakt hierop eene uitzondering; daar besteedt men in elke klasse 3 uur aan het Engelsch en in de hoogste zelfs 4; aan het Duitsch 1 uur in de 1e, 4 uur in de $2^{e}, 3^{e}$ en $4^{\mathrm{e}}$ en 3 uur in de $5^{\mathrm{c}}$ klasse. Vooral het ééne uur in de laagste klasse, voor schrijf- en leesoefeningen bestemd, laat zich uit een paedagogisch oogpunt bezwaarlijk verdedigen; mijne pogingen om hierin verandering te doen brengen, zijn tot dusverre vruchteloos geweest. Ook zie ik de noodzakelijkheid niet in om, zooals te Haarlem geschiedt, zooveel tijd aan de moedertaal en hare letterkunde te besteden, wanneer dit moet geschieden ten koste van andere, mijns inziens niet minder noodzakelijke vakken. Onder die noodzakelijke vakken tel ik bepaald de geschiedenis en aardrijkskunde; eerstgenoemd vak is te Haarlem, laatstgemeld te Dordrecht wel wat karig bedeeld; ook wordt nog niet overal genoeg acht geslagen op den hiervóór uitgedrukten wensch om de geschiedenis zooveel doenlijk van de lagere naar de hoogere klassen over te brengen.

Wat de wiskunde betreft, zoo heeft mij de ondervinding geleerd, dat men aan enkele scholen de stelkunde en meetkunde wel wat al te breed opvat; bij mijn bezoeken heb ik meermalen op inkrimping aangedrongen. Rekenen moet hoofdzaak blijven; van stelkunde behoeft slechts zeer weinig te worden behandeld en het onderwijs in meetkunde moet hoofdzakelijk dienen on de leerlingen te gewennen aan logische redeneering, en haar met enkele eigenschappen van figuren en lichamen bekend te maken, die bij natuurkunde en zelfs bij het rekenen te pas komen. Te Haarlem wordt betrekkelijk weinig tijd aan wiskunde besteed; de met dit vak belaste leeraar is tevens aan de jongensschool werkzaam en heeft niet meer tijd beschikbaar; ik hoop dat ook hierin met der tijd nog eenige verandering zal komen. Dat boekhouden zich binnen enge grenzen moet bepalen en zich uitsluitend met datgene moet bezig houden, wat de vrouw later kan te pas komen, spreekt wel van zelf. Welken weg men daarbij heeft in te slaan, is o. a. in het op sommige scholen ingevoerde leerboek van BIENTJES en KNAPPER duidelijk aangewezen. Aan de school te Groningen wordt geen onderwijs in boekhouden gegeven; aanvankelijk was het in het programma 
opgenomen; maar toen men voor het daarvoor bestemde salaris geen leeraar kon krijgen, heeft de gemeenteraad, hoewel tegen mịn advies, het uit de rij der leervakken geschrapt.

Ik kom nu tot eene belangrijke afdeeling van het onderwijs aan de meisjesschool, namelijk de natuurkundige wetenschappen en daarmede verwante vakken. Behalve de hiervóór reeds vermelde kleine wijziging, volgens welke iets minder tijd wordt besteed aan plant- en dierkunde, iets meer aan natuur- en scheikunde, en de beide laatstgenoemde vakken meer afzonderlijk worden behandeld, heb ik eigenlijk niets te veranderen in of toetevoegen aan hetgeen ik vóór zeven jaren daarover schreef. Over 't algemeen kan ik mij.ook zeer goed vereenigen met hetgeen Dr. Bromsars daarover in $n_{0} 26$ en 27 van "het Schoolblad" van 1876 heeft gezegd, al heeft hij zich wel wat veel moeite gegeven om Multapation te weerleggen, voor wien ${ }_{n}$ de middelbare scholen geen de minste waarde hebben, zoolang de voornaamste der aldaar gedoceerde wetenschappen, en inzonderheid schei- en natuurkunde, planten- en dierkunde niet geheel toegepast op hinishondkunde worden geleerd" (men zie zijne brochure bl. 7), en die daardoor duidelijk toont evenmin begrip te hobben van den aard en den omvang dier wetenschappen, als van de methode, volgens welke zij behooren te worden onderwezen. Ik ga echter niet met $D_{R}$. Br. mede, als hij de behandeling van de gezondheidsleer als afzonderlijk vak vordert. Ik trek het mij niet aan, dat hij mij eens heeft onderhanden genomen, omdat ik het gewaagd heb, in strijd met het advies van meer dan honderd en neertig geneesheeren uit Friesland, mij daartegen te verklaren; maar ik zou wel gewenscht hebben, dat hij meer rekening had gehouden met hetgeen ik vroeger over die zaak heb gezegd; ik heb namelijk mij nooit er tegen verklaard, dat bij de behandeling van de verschillende onderdeelen der natuurkundige wetenschappen het cen en ander betreffende gezondheidsleer zou worden ter sprake gebracht; uit mijn in 1870 geschreven opstel, en ook uit hetgeen ik later (Economist 1875, blz. 958) daarvan heb gezegd, blijkt duidelijk, dat ik mij alleen tegen de behandeling der gezondheidsleer als afzonderlijk leervak door eene specialiteit heb verklaard. Een degelijke behandeling is alleen mogelijk, nadat de leerlingen eenige kennis van natuurkunde, scheikunde en physiologie hebben opgedaan; de heer Bruinswa erkent zelf, dat zij is neene toepassing en uitbreiding in bepaalde richting van deze drie deelen der natuurwetenschap." Is het daarom niet rationeel, die uitbreidingen en toepassingen geleidelijk in de les van natuurkunde, scheikunde of dierkunde te 
laten behandelen door den leeraar dier vakken, wanneer die wetten of verschijnselen zijn ter sprake gebracht, waarvan zij de toepassing of uitbreiding zijn? Wie zou het in de gedachte krijgen om de talrijke andere toepassingen dezer wetenschappen op verschillend gebied, waarvan eenige kennis voor de leerlingen noodig is, in afzonderlijke uren te laten behandelen en aan specialiteiten op te. dragen? Men loopt nu gevaar, dat het gebied veel te groot zal genomen worden, zoo als men reeds aanstonds moet onderstellen, als men ziet, dat volgens het Arnhomsche programma aan natuuren scheikunde te zamen slechts zes uren zullen besteed worden, terwijl aan de toepassing daarvan op hygiene alleen twee uren zullen worden gewijd. Hoe het voorts mogelijk zal zijn reeds in de $4^{\mathrm{e}}$ klasse onderwijs in gezondheidsleer te geven (zooals voor Arnhem en Leeuwarden beide is voorgeschreven), terwijl de leerlingen dan nog slechts één jaar natuurkunde hebben geleerd en nog niets van scheikunde weten, is mij tot dusverre nog niet duidelijk geworden. Nog minder vat ik de bedoeling van de in het Arnhemsche programma opgenomen twee uren 's weeks in de 50 klasse voor eene afzonderlijke behandeling van de $n$ scheikunde toegepast op de voedingsleer", en wel door een anderen leeraar dan die, welke met het onderwijs in natuur- en scheikunde belast is. Ik dacht, dat dit wellicht was toeteschrijven aan mijne mindere kennis van scheikunde; maar een onzer bekwaamste chemici, die met ons middelbaar onderwijs van nabij bekend is, verklaarde mij, toen ik hem opheldering vroeg, evenmin te begrijpen, hoe men met voedingsleer aan een meisjesschool een cursus van twee uren 's weeks kan vullen.

Gelukkig heeft men nog nergens gevolg gegeven van MOLTAPa TIOR's weusch, dat aan de meisjesscholen onderwijs zal worden gegeven in luuishoudkunde. De voorstanders van dit stelsel (gelukkig zijn or niet velen; voor zooveel mij bekend is tot dusverre, behalve hem en Constant, alleen de redactie van „de Tijdspiegel", blijkens haar antwoord aan $\mathrm{Dr}_{\mathrm{r}} \mathrm{Br}$. in de aflevering van October jl.) gaan uit van het denkbeeld, dat de school moet dienen om aan de meisjes kennis van al datgene mede te deelen, wat haar later als huisvrouw en moeder kan te pas komen; zij blijven evenwel in gebreke aan te toonen, wat eigenlijk in die lessen moet worden behandeld, in welke de meisjes moeten worden voorbereid om "huisvrouw en moeder te worden." Er zijn nu reeds ouders, die zich ergeren, als in de les van plantkunde een zaadkorrel "een bevrucht eitje" genoemd wordt; hoe zal het wel gaan, als de moederplichten in 
de les ter sprake komeu? En aan wie zal dat onderwijs opgedragen worden? Toch niet aan de gewone onderwijzeressen, die in den regel noch huisvrouw, noch moeder geweest zijn? Wil men soms huisvrouwen en moeders aan de school verbinden, alleen om dit onderwijs te geven? Men moet al heel weinig begrip hebben van onderwijs en van de inrichting eener school, om zoo iets te willen; bovendien.schijnt men zeer weinig verwachting te hebben van de degelijkheid onzer Nederlandsche vrouwen, als men haar zelfs de opvoeding harer dochters op huishoudkundig gebied niet durft toevertrouwen! Dat ik niet alleen er zoo over denk, kan blijken uit de volgende door Dr. Bruinsms in $n^{0} .31$ van "het Schoolblad" medegedeelde uittreksels uit brieven van Directrices van meisjesscholen :

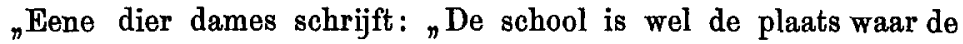
ngeest ontwikkeld, de grondslag tot kennis gelegd en daarmee in „verband het hart gevormd moet worden, maar wat overigens meer nbijzonder de meisjes zullen noodig hebben tot hare bestemming nals vrouw en moeder, dat kan de school niet bijbrengen, al moet nhet ook daar nooit uit het oog worden verloren. Handigheid voor „huiselijken vrouwelijken arbeid, kookkunst enz., die eene vrouw zeker nonmisbaar zijn, zou men op de school kunnen onderwijzen?" En op de bedenking van sommigen, dat meerdere ontwikkeling, zooals die op de tegenwoordige scholen verkregen wordt, de meisjes van huishoudelijken arbeid af keerig zal maken, antwoordt $z \mathrm{ij}:{ }_{n} \mathrm{\Pi k}$ "heb de innige overtuiging, dat hooge verstandsontwikkeling wel "verre van het meisje voor huiselijk werk onverschillig te maken, "ook in dat opzicht heilzaam moet werken." Eene der andere directrices schrijft omtrent de meer algemeene ontwikkeling, die op de middelbare school aan het meisje gegeven wordt: „Zal zij daarom ${ }_{n}$ minder goed hare plichten als huishoudster waarnemen? $\mathrm{Ik}$ geloof nhet niet; haar beter ontwikkeld verstand is, dunkt mij, reeds een "waarborg van het tegendeel, afgezien van het feit, dat, op kleine "uitzonderingen na, die er altijd geweest zijn, alle vrouwen groote nneiging gevoelen tot huishoudelijke bezigheden en eene aangenboren geschiktheid er voor bezitten. De plichten, die de vrouw nals huishoudster te verrichten zal hebben, op de school aan te "leeren, gaat moeielijk, tenzij Multapatior wil dat men bij de "middelbare school een gaarkeuken hebbe. Multapatior ziet de "moeielijkheid van de huishoudkunst wel wat heel zwaar in. Daar"enboven trouwen de meisjes gewoonlijk niet zoo dadelijk na het nverlaten der schoolbanken. Kunnen we nu niet van de moeders 
"verwachten, dat zij hare dochters met alle geheimen der huis"houding bekend maken, gedurende den tijd die het huwelijk voor${ }_{n}$ afgaat? Hoe zal men op de school aan een meisje leeren kleine "kinderen te verzorgen en zieken te verplegen? Toch niet door "voudelingshuizen en hospitalen met de middelbare school te verbin"den?" De derde der dames, die zich over dit punt uitlaat, schrijft: "Multapatior wil dat op de middelbare school het meisje gevormd "zal worden tot hare taak als "huisvrouw en moeder" en daarmeo „wil hij 't onmogelijke. M. vergeet één ding: de opvoeding aan „den huiselijken haard. Hij vraagt alles van de school. Wat Mul"tapatior wil is een broeikas-methode, en zal, vrees ik, tot nog "meer ongezonds en opgeschroefds leiden, dan we reeds zien." Zij geeft verder toe, dat er wel iets goeds is in hetgeen Multapatior van de middelbare school verlangt, maar dat juist dit goede - natuurwetenschappelijk onderwijs met het oog op huishoudelijken arbeid en gezondheidsleer - aan alle scholen, waar de docenten hun taak goed opvatten, reeds bestaat. Maar het denkbeeld van Multapatior, dat de school de toekomstige huisvrouw ${ }_{n}$ ijver, nauwgezetheid, spaarzaamheid, huishoudkunde" moet leeren - anders dan door algemeene ontwikkeling van verstand, gevoel en waarnemingsvermogen - noemt zij kortweg nonzin". Hiermede is niet gezégd, dat geen meisje meer behoeft te leeren dan op de tegenwoordige middelbare scholen onderwezen wordt. Behalve hetgeen zij in huis leeren, zouden enkele der dames die mij schreven, en andere die ik sprak, 't wel zeer wensohelijk achten, indien er inrichtingen bestonden - geen sclolen dan - waarin het volwassen meisje de bekwaamheid in allerlei schijnbaar nietige, maar inderdaad zeer belangrijke verrichtingen kon verkrijgen. Dit is echter iets geheel afgescheiden van de tegenwoordige middelbare scholen voor meisjes, en thans geen punt van behandeling. De gronden, waarop alle later te verkrijgen kennis en bekwaamheid moeten steunen, die worden op de middellsare school gelegd; dit is het voornaamste."

Bedrieg ik mij niet, dan zijn in enkele groote steden van Duitschland zoodanige inrichtingen, waar gelegenheid wordt gegeven aan jonge vrouwen of meisjes om het een en ander van huishoudkunde te leeren. Multapation schrijft aan het slot van zijn opstel: ${ }_{n} \Pi_{k}$ breng alles in ngereedheid om eene inrichting in het leven te roepen, waar aan ${ }_{n}$ meisjes uit alle standen der maatschappij theoretisch en pralktisch "onderwijs in de huishoudkunde zal worden verstrekt." Ik zal niet in eene beoordeeling treden van hetgeen hij verder mededeelt omtrent de wijze, waarop hij an dat denkbeeld wenscht uitvoering 
to geven; maar komt iets in dien geest tot stand, en zijn er meisjes, welke de gelegenheid missen om in huis onder de leiding der moeder eenige ondervinding op huishoudelijk gebied op te doen, dan hoop ik althans, dat zij van MULtapation's school of scholen eerst zullen gebruik maken, nadat zij de middelbare school, zooals zij thans is ingericht, zullen doorloopen hebben.

Aan teekenen wordt $m$. $i$. aan verscheidene scholen nog te weinig tijd besteed; met twee uren 's weeks in elke klasse (in Arnhem zelfs nog minder) is niet veel uit te richten; Rotterdam, Dordrecht en Groningen staan in dit opzicht boven aan; aan de beide eerstgenoemde wordt ook onderwijs in schoonheidsleer of kunstgeschiedenis gegeven, te Dordrecht door den leeraar in teekenen; dit acht ik verkioslijk boven opdracht aan een afzonderlijken docent; maar ik moet de moeilijkheid erkennen om leeraren te vinden, geschikt, om goed onderwijs te geven in handteekenen en tevens op onderhoudende wijze mondeling de schoonheidsleer te behandelen. Wordt gevolg gegeven aan de plannen der Regeering om voor een betere en breedere opleiding onzer aanstaande teekenleeraren te zorgen, dan is misschien in dit opzicht ook op een betere toekomst to rekenen.

Afzonderlijke lessen in het schrijven acht ik niet noodig. De „klassieke oudheid" is met de wijziging van het Arnhemsche programma, naar ik hoop voor goed, als afzonderlijk vak van het programma der meisjesscholen verdwenen. Daarentegen heeft het nieuwe programma dier school voor elke der beide hoogste klassen een uur ${ }_{n}$ ziel- en opvoedkunde." Tot dus verre werd dit vak alleen op de kweekscholen voor onderwijzers en onderwijzeressen behandeld; menigmaal werd mij verzekerd door deskundigen, die van nabij met die inrichtingen bekend zijn en bij de acte-examens voor het lager onderwijs er de resultaten van hebben leeren kennen, dat deze voor de jeugdige leerlingen veel te wenschen overlieten. Zal men aan de middelbare school te Arnhem met meisjes van 15 tot 17 jaren gelukkiger zijn? De tijd zal het moeten leeren. Maar welke ook de uitkomsten zijn, het vak behoort $\mathrm{m}$. i. op eene middelbare school niet thuis; het is weer dezelfde overdrijving, die wil dat kinderen op school alles zullen leeren, wat hun later als volwassen menschen misschien zal kunnen te pas komen.

Over zangoefeningen heb ik hiervóór reeds een woord gezegd om het wenschelijke aan te toonen van die facultatief te stellen. Het ééne uur, dat te Haarlem aan zoodanige oefeningen besteed wordt, 
zal wellicht tot verwondering aanleiding geven. Volgens het programma is het bestemd voor de laagste klasse; verder leest men daar: ${ }_{n}$ Het onderwijs in den zang in de vier hoogste, en in het schoonschrijven in de beide laagste klassen wordt door de Directrice geregeld." Mocht men soms de opmerking maken, dat de zaak hierdoor nog niet veel duidelijker wordt, dan moet ik opmerken, dat, blijkens de inlichtingen, die men de goedheid had mij dienaangaande schriftelijk te geven, het doel schijnt te zijn de leerlingen niet op vaste tijden, maar slechts nu en dan eens een kwartier of een half uur te laten zingen, als zij wat minder opgewekt zijn; in schrijven wordt geen afzonderlijk onderwijs gegeven; dat ik dit laatste volkomen goedkeur, blijkt uit het zooeven opgemerkte.

Gymnastiok wordt aan alle scholen van vijfjarigen cursus onderwezen, behalve te Dordrecht; aan sommige kon er meer werk van worden gemaakt. Het dansen to Groningen zou ik liever door eenvoudige gymnastische oefeningen vervangen zien.

Tk heb bij de voorgaande beschouwingen de scholen van driejarigen cursus onvermeld gelaten. Die te Goes, welke grootendeels schijnt overeen te zullen komen met de drie (of vier?) laagste klassen der volledige inrichtingen, staat in zekeren zin op zich zelf; daar zij eerst voor weinige maanden geopend is en nog niet volledig in werking is, vordert de billijkheid het oordeel nog eenigen tijd uit te stellen; het programma komt grootendeels overeen met dat van de lagere klassen van den vijfjarigen cursus, alleen met dat onderscheid, dat meer tijd wordt besteed aan de fransche taal, waarvan geen kennis wordt gevorderd bij de toelating, als ook aan natuurwetenschap; het aantal lesuren per week bedraagt voor elke klasse 32 ; van de hiervóór genoemde afzonderlijke vakken, welker behandeling als zoodanig ik meende te moeten afkeuren, komt er geen enkel voor.

Aangaande de scholen van driejarigen cursus te Amsterdam, Utrecht en Deventer kan het volgende worden medegedeeld. Te Utrecht wordt meer tijd aan vreemde talen besteed; daar komt echter geen gymnastiek, noch staatsinrichting op het programma voor. Te Amsterdam en te Deventer mist men onderwijs in handwerken, aan eerstgenoemde ook in gymnastiek. Aesthetica of kunstgeschiedenis wordt aan alle drie onderwezen, te Utrecht 1 uur, te Amsterdam 2, te Deventer 3 uren per week; aan staathuishoudkunde en gronden der staatsinrichting worden te Deventer 3 , te Amsterdam 2 uren gewijd. Elke dezer scholen heeft minstens 
3 uren 's weeks in elke klasse voor teekenen bestemd, voor wiskunde en boekhouden in 't geheel 10 of 11 uren. Voor natuurwetenschap bedraagt het getal 12 of 13 ; wat de verdeeling der verschillende onderdeelen over de drie klassen betreft, trok het mijne aandacht, dat te Utrecht 6 uren bestemd zijn voor natuurkunde, terwijl alleen in de hoogste klasse één uur aan scheikunde wordt gewijd, en in diezelfde klasse een uur onderwijs in gezondheidsleer wordt gegeven en wel door een anderen leeraar; ook to Deventer wordt scheikunde gedurende 2 uren 's weeks uitsluitend in de hoogste klasse behandeld. Te Amsterdam bedraagt het getal lesuren per klasse 28 tot 30 , te Utrecht 32 , te Deventer 30 tot 32.

Vraagt men, welke tot dusverre de resultaten van het onderwijs aan de meisjesscholen zijn? Ik zou liever zien, dat andere volkomen onpartijdige beoordeelaars het antwoord op die vraag gaven; mij toch zal men wellicht in dit opzicht, evenzeer als de directrices der scholen zelve, van partijdigheid verdenken. Aan hen, die in weerwil daarvan aan mijn oordeel eenig gewicht hechten, wil ik echter gaarne bekennen, dat de uitkomsten der middelbare scholen voor meisjes verreweg de goede verwachting overtroffen hebben, die ik voor zeven jaren er van koesterde. Nooit zag ik meer belangstelling in het onderwijs, meer leerlust, meer hart voor de school, dan bij de leerlingen van de zes onder mijn toezicht geplaatste meisjesscholen, welke ik meermalen heb bezocht en in bijzonderheden nagegaan, en ik twijfel niet of bij de vier andere zal zulks evenzeer het geval zijn. Wilde ik eene aanmerking maken, het zou eer zijn op te veel ambitie dan op te woeinig; moeten de leerlingen der jongensscholen wel eens tot werken aangezet worden, bij de meisjes is dit eene zeldzaamheid, terwijl het daarentegen meermalen is gebeurd, dat de leerlust moest getemperd worden.

Een enkele maal is wel eens de vraag tot mij gericht: wordt er niet te veel van de meisjes gevorderd? Is de school niet uitsluitend geschikt voor zeer begaafde, ongeschikt voor de middelmatige? Hoewel het niet geheel te ontkennen is, dat de groote ambitie van sommige vlugge leerlingen wel eens op enkele minder begaafde ontmoedigend werken kan, zoo moet ik toch die vragen bepaald ontkennend beantwoorden. Als bewijs daarvan kan de uitslag der overgangs-examens worden aangevoerd, die voor de meisjesscholen steeds veel gunstiger was dan aan de hoogere burgerscholen voor jongens. Ook verliest men uit het oog, dat de omvang van het onderwijs, dat in de lagere klassen der 
middelbare school voor meisjes gegeven wordt, slechts weinig verschilt van dien op de school voor meer uitgebreid lager onderwijs; de moedertaal, drie vreemde talen, geschiedenis en aardrijkskunde, rekenen, teekenen, handwerken treft men op beide aan; de "kennis der natuur," op vele lagere scholen voor meisjes te veel verwaarloosd, wordt vervangen door goed georganiseerd onderwijs in plant- en dierkunde, waarbij eerst in hoogere klassen natuurkunde en scheikunde komen. Het groote verschil bestaat in de betere organisatie der middelbare school en de hoogere eischen, die aan het onderwijzend personeel worden gesteld. Opmerkelijk is het oordeel van eene der Directrices, door Dr. Brorssma medegedeeld; deze schreef hem: „Ik heb meer dan ééne goede kostschool van zeer nabij ngekend, ben zelf aan twee middelbare scholen werkzaam geweest, "on kan verzekeren, dat de resultaten zeer voor de laatste plei"ten; althans indien men bij de beoordeeling het zwaartepunt wil nzoeken in meerdere ontwikkeling en kennis, en niet in het, dik${ }_{n}$ wijls ook maar zoogenaamd, gemakkelijk spreken der vreemde "talen, wat door sommige ouders, die niet tot de verstandigste "belıooren, zoo vaak als een hoofdzaak wordt beschouwd."

Wil men eene afdoende proef, men richte zich tot de meisjes, die de school geheel hebben doorloopen. Er zijn er reeds een vrij aanzienlijk getal, die in dit geval verkeeren; enkele hebben na het verlaten der school nog hare studiën voortgezet en een examen voor lager of middelbaar onderwijs gedaan; maar de meeste zijn eenvoudig in den huiselijken kring teruggekeerd om onder de leiding van hare moeder hare opvoeding te voltooijen. Zoo wel zij zelve als hare ouders zijn in staat om over de resultaten te oordeelen, en ik ben zeker, dat het oordeel gunstig, zelfs zeer gunstig zal zijn.

Ik moet ten slotte nog één punt meer in 't bijzonder ter sprake brengen, waarvan boven slechts in het voorbijgaan werd gewag gemaakt, namelijk de toelating van meisjes tot de hoogere burgerscholen voor jongens. In 1871, naar ik meen,-werd het eerst tot den Minister van Binnenlandsche Zaken door een ingezetene van Sappemeer het verzoek gerioht, dat zijne dochter tot de aldaar bestaande Rijks hoogere burgerschool zou worden toegelaten. Het verzoek werd toegestaan, nadat door den Minister THorbecke tot den Directeur de vraag was gericht, "of er iets was in den geest en nden gang van het onderwijs, in de zamenstelling van het personeel, nin den geest der leerlingen, dat als beletsel voor toelating zou „kunnen gelden?"; het spreekt wel van zelf, dat zoodanige vraag 
door geen Directeur, die zorgt, dat aan zijne school een goede geest en orde heerschen, bevestigend kon worden beantwoord, en dat dus zoowel te Sappemeer, als later aan andere scholen de vergunning werd gegeven. Dat deze maatregel tegenspraak zou vinden, was te verwachten; nog het zelfde jaar werd hij door den Heer Mr. J. B. Baron tan Hugenpoth tot den Berenclauw in de vergadering van de Vereeniging voor de Slatistiek ter sprake gebracht; ik maakte van die gelegenheid gebruik om mijne geringe ingenomenheid met die toelating te kennen te geven. Ook in de Tweede Kamer werd de zaak ter sprake gebracht, zonder dat er echter eenige verandering in kwam; in "de Tijdspiegel" van 1872 schreef Dr. C. G. van Reeren te Haarlem (als lid der Commissie van Toezicht op het middelbaar onderwijs en medebestuurder van de daar gevestigde Kweekschool voor onderwijzeressen van nabij met de vereischten van goed onderwijs voor meisjes bekend) een uitstekend opstel, waarin vooral de zaak uit een physiologisch en psychologisch oogpunt werd besproken. De na den heer Thorbecke opgetreden Ministers van Binnenlandsche Zaken gingen op den eenmaal ingeslagen weg voort, wat de Rijks hoogere burgerscholen betreft, en, zoo als te verwachten was, volgden enkele gemeentebesturen voor hunne hoogere burgerscholen dit voorbeeld. In de volgende tabel is aangewezen, aan welke jongensscholen in de laatste zes jaren meisjes zijn toegelaten, en hoeveel.

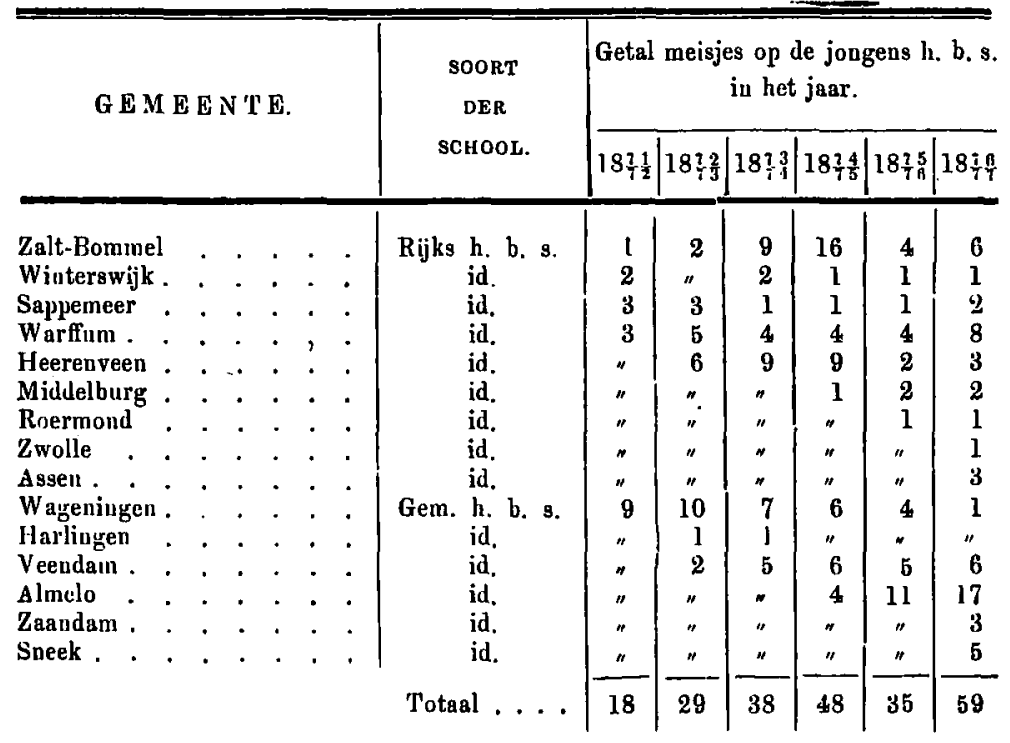




\section{4}

$\mathrm{Na}$ eenigen achteruitgang in 1875 , heeft er dus dit jaar weder een vrij aanzienlijke vermeerdering plaats gehad, zoowel in het getal der scholen als in het getal der toegelaten leerlingen; alleen te Harlingen is men van den, mijns inziens, verkeerden weg terug gekeerd en heeft men bij eene reorganisatie der school in 1874 in het reglement de bepaling opgenomen, dat geen meisjes zullen worden toegelaten. Voor de Rijksscholen te Zwolle en te Assen is de vergunning verleend door den tegenwoordigen Minister van Binnenlandsche Zaken, die echter geen algemeene vergunning heeft gegeven, maar voor zooveel het getal toetelaten leerlingen betreft zekere regelen schijnt te willen stellen. De billijkheid vordert te erkennen, dat het moeilijk is in de zaak verandering te brengen, nadat eenmaal door den ontwerper zelven der wet de vergunning was verleend; ik had echter wel gewenscht, dat men zich tot de vroeger gegeven vergunningen had bepaald en geene nieuwe, vooral niet aan andere scholen, had gegeven. Dat de Minister HeEMSKerk trouwens zelf geen voorstander is van de vereeniging van jongens en meisjes van 12 tot 17 jarigen leeftijd in dezelfde school blijkt daaruit, dat op de Staatsbegrooting voor 1877 eene verhooging van het Rijkssubsidie voor de gemeentelijke hoogere burgerschool te Almelo is voorgesteld, $n$ ten einde aan de "klassen der hoogere burgerschool afdeelingen te verbinden, inge"richt naar den aanleg en de behoeften van meisjes", en wel omdat nhet getal der vrouwelijke leerlingen gaandeweg is toegenomen „ en eerlang dat der mannelijke leerlingen zal overtreffen, terwijl ${ }_{n}$ der gemeente de middelen ontbreken tot het vestigen en onder"houden eener afzonderlijke middelbare school voor meisjes."

Te Zaandam en Sneek heeft de gemeenteraad dit jaar voor het eerst besloten meisjes tot de jongens hoogere burgerschool toe te laten. In eerstgenoemde gemeente was de zaak reeds voor eenige jaren ter sprake gebracht; ik bad toen een vrij uitvoerig advies tegen het door enkele ingezetenen ingezonden verzoek uitgebracht, en de Raad vereenigde zich met mijn gevoelen. In het begin van 1876 is men echter weder op de zaak teruggekomen; de Commissie van Toezicht adviseerde voor de toelating; ook de Directeur, hoewel niet bijzonder met de zaak ingenomen, verklaarde zich er niet tegen. Ik kon mij grootendeels op mijn vroeger advies beroepen, daarbij nog uitdrukkelijk wijzende op eene bestaande meisjesschool voor meer uitgebreid lager onderwijs, die mij voorkwam, met eenige wijziging en uitbreiding, beter dan de hoogere burgerschool aan de behoeften van het rrouwelijk geslacht te kunnen beant- 
woorden. Nogtans werd in de Raadszitting de zaak zoodanig voorgesteld, alsof $\mathrm{ik}$ eigenlijk geen tegenstander was en - de vergunning werd verleend, zoodat mij niets overbleef dan in 't openbaar te protesteeren tegen de onjuiste uitlegging, door enkelen aan mijne woorden gegeven. Te Sneek waren de Commissie van Toezicht en ik het volkomen eens, dat de toelating van meisjes niet wenschelijk was; ook daar bestond eene meisjesschool voor meer uitgebreid lager onderwijs, waarvan de hoofdonderwijzeres zelfs met gunstigen uitslag examen voor middelbaar onderwijs had gedaan; onze uitvoerige adviezen strekten dan ook om de zaak uitdrukkelijk af te raden. Wat in den Raad daartegen is ingebracht, is een diep geheim, want - hoe ongeloofelijk het moge schijnen - de zaak werd in eene gesloten raadsvergadering behandeld en daarna besloten, dat de school evenzeer door meisjes als door jongens kan worden bezocht!

Hoewel ik, na alles wat nu en vroeger door mij is gezegd over de organisatie van middelbaar onderwijs, ingericht naar de behoeften van meisjes van 12 tot 18 jaren, geen uitvoerig betoog behoef te leveren om de ondoelmatigheid van gelijk en gelijktijdig onderwijs aan jongens en meisjes aan te toonen, zoo wil ik toch nog enkele der argumenten mededeelen, die m. i. daartegen kunnen worden aangevoerd. Dat het de bedoeling van den wetgever niet is geweest, de hoogere burgerscholen ook voor meisjes te bestemmen, is door den heer vAN HUGENPOTH zoo duidelijk aangetoond, dat daartegen niets scheen te kunnen worden aangevoerd, dan ${ }_{n}$ dat de wet die toelating niet verbiedt"; doch ook van dit argument werd door hem de onhoudbaarheid duidelijk in het licht gesteld; te recht plaatste hij eene uitdrukking, door den Minister Thorbecke zelven gebruikt bij gelegenheid van het voorstel der heeren JoNCKBLOET en VAN KERKWIJK om de oprichting van middelbare meisjesscholen te bevorderen, op den voorgrond; die Minister had namelijk gezegd: "Derhalve meen ik te mogen aan"nemen: het is in confesso, het wordt door de geachte voorstellers "erkend: de middelbare school voor meisjes moet iets anders wezen dan "de middelbare school, ingesleld en gerpgeld bij de wet van 1863." (Economist 1871, pag. 1083 en volgg.)

Van meer gewicht echter dan de rechtskwestie is in mijn oog de vraag, of uit een paedagogiseh oogpunt de vereeniging van jongens en meisjes van 12 tot 18 jaar in de zelfde school wenschelijk is? Dr. von REEKEN heeft in zijn bovenvermeld opstel duidelijk het verschil in aanleg en bestemming van beide in het licht gesteld 
en ik moet erkennen, dat de ondervinding, welke ik in de laatste jaren van het onderwijs aan meisjes en jongens heb opgedaan, mij de juistheid heeft aangetoond van datgene, wat hij op zuiver theoretische gronden afleidt uit het physiologisch en psychologisch verschil tusschen man en vrouw. De voornaamste zijner conclusiën zijn de volgende:

„Haar gemoedsleven, minder beheerscht door een kalm oordeel n en een krachtigen wil, ontvangt niet alleen tal van gewaarworndingen, doch hecht zich aan deze zonder haar waarde voldoende ${ }_{n}$ te onderzoeken. Dit geeft aanleiding, dat het oordeel wel snel, n doch meer oppervlakkig gevormd is, terwijl het geheugen minder ngeoefend wordt. De handelingen der vrouw worden over ' $t$ alge"meen dan ook meer. bestiord door het gevoel dan wel door de ${ }_{n}$ rede; zij is meer deelnemend, haar kinderliefde en godsdienstig ngevoel zijn inniger, haar zedelijkheid grooter en haar fantasie rijker. ${ }_{n}$ Deze neiging om veel waar te nemen en snel te oordeelen geeft ${ }$ der vrouw wel een vlug oordeel, maar waar dit behoort door te "dringen in een ingewikkelde verhouding of een diepzinnige na${ }_{n}$ vorsching, daar is de opgenomen gewaarwording onvoldoende $n$ geassimileerd om een nader onderzoek toe te laten. Vluchtig als n ze kwam, werd ze door tal van anderen opgevolgd en verdrongen, „en oordeel en wil missen door gebrek aan aanleg of oefening ${ }_{n}$ eerder het vermogen zich tot enkelen te bepalen.

„Van de gewaarwordingen door den man ontvangen worden er "minder met zelf bewustheid opgenomen; de receptiviteit schijnt n zwakker wat de uitgebreidheid aangaat, doch wat de intensiteit „ van het waargenomene betreft, schijnt deze sterker te zijn en vooral ${ }_{n}$ zich te bepalen tot die gewaarwordingen, welke met het wezen ${ }_{n}$ der dingen in naauw verband staan.... Het is een feit, dat de n man meer zijn oordeel en wil bepalen kan en vaak bepaalt tot het "navorschen van enkele gewaarwordingen, in het wezen van deze "dieper doordringt, zich daaraan met meer energie wijdt. Zijn " geringere zenuwprikkelbaarheid leidt hem daarvan minder af en $n$ stelt hem zoodoende in staat niet te rusten voor zijn ondern zoek geöindigd, zijn navorsehing geschied of zijn uitvinding „ voltooid is. Bijna alles op het gebied van wetenschap en kunst n of voor het leven van gewicht is van hem af komstig.

${ }_{n}$ Kan het ander's of die grooter energie, die sterkere wilskracht "maakt zijn hartstochten heftiger, zijn fantasie koener, zijn hann delingen meer consequent, doortastend en ruw; maar ook daardoor n mist hij in tergenspoed de kalme gelatenheid der vrouw; zij, de 
n minder krachtige, die met minder energie de ontvangen indrukken n opneemt, duldt met grooter standvastigheid de rampspoeden des nlevens.

n....Geef den man een vrouwelijke opleiding of doe geweld aan n zijn aanleg, en hij zal met zich zelf niet tevreden kunnen zijn; n ontwikkel bij voorkeur zijn gemoedsleven, en zijne diepte van ᄁ oordeel en sterkte van wilskracht zal er onder lijden, zijn over${ }_{n}$ tuiging van hetgeen hij recht en waar achit en waarvoor hij $n$ strijdende zou willen sterven, kan zich dan minder krachtig uiten, n omdat zijn gemoedsleven er tegen in opstand komt en hem weifel${ }_{n}$ moedig maakt. Geef der vrouw evenzeer eene opleiding in strijd „ met haar aanleg en zij zal door hare eigenaardige constitutie nzich zwak en onberredigd gevoelen; en al ware het mogelijk, "dat bij voortgezette leiding in dien zin, bij opvolgende geslachten, „door cultuur, de vrouw dezelfde eigenschappen des geestes als „ de man verkreeg, dan nog zal haar eigenaardige lichaamsver$n$ houding voor haar een beletsel blijven om een plaats te bekleeden "in de maatschappij, welke beantwoordt aan de door haar alsdan "te stellen eischen."

Mag men dit aannemen, - en ik geloof niet, dat het door een deskundige zal worden in twijfel getrokken, - dan ligt ook het gevolg bij de hand, dat niet alleen de leerstof voor jongens en meisjes niet geheel dezelfde behoort te zijn, maar dat zelfs bij de wijze van behandeling op versehil in amleg bij de twee geslachten behoort te worden acht gegeven; en dat derhalve het onderwijs, zooals het aau de hoogere burgerscholen voor jongens wordt gegeven, in omvang en in methode aanzienlijke wijziging zou moeten ondergaan, om tevens voor meisjes geschikt te worden. De voorstanders van het stelsel van gezamenlijk onderwijs beweren dat, aangezien verstandelijke ontwikkeling het hoofddoel is van de hoogere burgerschool, het daar gegeven onderwijs even goed voor meisjes als voor jongens kan dienen; zij verliezen echter daarbij uit het oog, dat niet alle middelen tot het geven van die ontwikkeling dezelfde zijn, dat dikwijls voor verschillende individu's van hetzelfde geslacht andere middelen moeten worden angewend, en dat dus a fortior $i$ voor de verschillende geslachten die middelen moeten verschillen, daar èn aanleg èn bestemming bij beide niet dezelfde zijn.

De ondervinding heeft geleerd, dat bij het onderwijs in taal-en letterkunde, vooral ook bij de appreciatie van, het gelezene, het meisje den jongen overtreft; zij zal opgewekt en medegesleept worden door letterkundige voortbrengselen, die den jongen tamelijk

EcoN. 1877. 
koud en onverschillig laten. Daarentegen, waar het verstand en de faculteit om gevolgtrekkingen en combinatiën te maken meer werkzaam moeten zijn, zoo als bij de beoefening van wiskundige en natuurkundige wetenschappen, bij de aardrijkskunde, zooals zij thans behoort te worden onderwezen, moet bet meisje bij den jongen achterblijven; wat voor hem aanstonds duidelijk is, zal door haar eerst na herhaalde verklaring begrepen worden. Reeds in de lagere school kan men dit opmerken; jongens, die op ongeveer twaalfjarigen leeftijd die school verlaten, hebben in den regel beter begrip van rekenkunde dan meisjes van denzelfden leeftijd. Dit zal ten gevolge hebben, dat men, bij de toelating van meisjes, ten haren behoeve onwillekeurig het peil eenigszins zal verlagen, of wel dat men de meisjes eerst op hoogeren leeftijd tot de laagste klasse zal moeten toelaten, dan met de jongens in den regel het geval zal zijn. Bleef het daar nu bij, dan zou in het eerste geval het verlies misschien nog kunnen worden ingehaald; maar juist het tegendeel zal het geval zijn; door mindere geschiktheid voor wiskundige studie zal de kloof al grooter en grooter worden; de meisjes zullen dus bij de jongens moeten achterblijven, of de jongens zullen door de tegenwoordigheid van meisjes in hunne vorderingen belemmerd worden, indien, zoo als te verwachten is, de leeraren conscientieus genoeg zijn om de vrouwelijke leerlingen niet aan haar lot over te laten, maar zorgen, dat de vorderingen van de vluggere jongens zich naar die der meisjes regelen. Het gevolg hiervan zal zijn, dat de jongens, als zij eenmaal tot de $3 e$ klasse zijn gevorderd, veel minder van wiskunde weten dan thans het geval is; dit zal op hun vorderingen in de alsdan te behandelen natuurkundige wetenschappen ook weer een nadeeligen invloed uitoefenen; worden de lessen in natuurkunde eveneens door de meisjes bijgewoond, dan zal dit een nieuwe reden zijn, waarom het onderwijs ingekrompen en anders ingericht moeten worden. Het is ook mogelijk, dat de meisjes, door ambitie gedreven, door groote inspanning trachten niet voor de jongens onder te doen; maar ' $t$ is de vraag, of dit zonder groote schade voor hare gezondheid zal kunnen gebeuren.

In de lessen van taal- en letterkunde zullen daarentegen de meisjes gemakkelijk de jongens voórbijstreven; heeft men ze, uit hoofde van mindere kennis van 't rekenen, eerst op wat hoogeren leeftijd toegelaten, dan weten zij waarschijnlijk reeds veel meer van taalkunde dan de jongens; ten gelieve van deze moeten zij dus weer worden achteruit gezet, en de tegenwonrdigheid van de jongens belet haar zulke vorderingen te maken, als anders het geval zou zijn. 
Hoe ik de zaak ook beschouw, ik kan tot geen ander besluit komen, dan dat het stelsel der gemengde middelbare school nadeelig moet werken op de vorderingen, zoowel van de meisjes als van de jongens, en dat ten slotte langzamerhand het geheele stelsel der jongensschool door de toelating van meisjes zal worden in de war gebracht. Dit zal natuurlijk het meest merkbaar zijn, indien het getal vrouwelijke leerlingen aanzienlijk is; maar ook bij tegenwoordigheid van weinige zal het zich op den duur doen gevoelen, indien de leeraren althans niet zich bij hun onderwijs richten naar de behoeften van de meerderheid en die van de meisjes daaraan opofferen; is dit laatste het geval, dan behoeft het geen betoog, dat zij verreweg verstandiger doen door van de aangeboden gelegenheid geen gebruik te maken.

Een in mijne oogen belangrijk argument tegen de combinatie is nog gelegen in het doel der school, dat niet alleen moet bestaan in het mededeelen van nuttige kennis, maar ook in opvoeden en beschaven. Men heeft wel eens an de leeraren der hoogere burgerscholen ten laste gelegd, dat dit doel niet genoeg wordt in het oog gehouden; maar hoe zal het hun mogelijk zijn het opyoedkundig element meer op den voorgrond te plaatsen, als hun leerlingen bestran uit jongens en meisjes van 12 tot 18jarigen leeftijd, die in dit opzicht geheel verschillendè behoeften hebben, in welke door geheel andere middelen moet worden voorzien? Het opvoedend element zal dus nog veel meer dan thans op den achtergrond komen, zoo al niet ten eenemale verwaarloosd worden. Waarlijk, de tegenstanders der middelbare scholen hadden geen beter middel kunnen bedenken om haar in hare ontwikkeling tegen te houden en de middelen, die tot haar verbetering worden aangevoerd, vruchteloos te maken! Voor jonge docenten, die nog ervaring op paedagogisch gebied moeten opdoen en reeds moeite hebben om alleen bij jongens de orde te handhaven en een goede methode bij hun onderwijs te kiezen, zullen zich bij de gemengde klassen zooveel moeilijkheden voordoen, dat zij groot gevaar loopen feil op feil te stapelen en dat hun onderwijs geen of weinig vruchten afwerpt; en men zal het recht niet hebben hun dit ten kwade te duiden, want ieder ervaren leeraar in wis- en natuurkundige wetenschappen zal mij moeten toestemmen, dat het niet mogelijk is het onderwijs roor meisjes en jongens te gelijk op doelmatige wijze en zoo, dat het aan beider behoeften voldoet, interichten.

Het argument, dat bij mij het minst zwaar weegt, is datgene, hetwelk door sommigen op den voorgrond wordt gesteld, die 
namelijk uit een zedelijk oogpunt van het bezoek van dezelfde school door jongens en meisjes schromelijke gevolgen vreezen. Ik wil niet beweren, dat in dit opzicht de gevolgen niet verkeerd kunnen zijn; maar gelukkig heerscht er, op geringe uitzonderingen na, aan de hoogere burgerscholen zulk een goede orde, dat ik niet twijfel of de directeuren zullen ook deze zwarigheid wel te boven komen, al wordt hunne taak er dan ook eeniggzins door verzwaard. Ik moet erkennen, dat mij betreffeude scholen, waar ook meisjes tot de lessen worden toegelaten, nog nimmer iets is ter ooren gekomen, dat uit dien hoofde alleen het stelsel zou moeten doen verwerpen.

Uit alles wat hiervóór is gezegd blijkt, dat naar mijne meening voor het middelbaar onderwijs aan meisjes geheel andere eischen moeten worden gesteld dan aan dat voor jongens van denzelfden leeftijd, en dat de voor laatstgemelde bestemde school niet geschikt is om in de behoeften van het vrouwelijk geslacht in dit opzicht te voorzien, terwijl aan den anderen kant de tegenwoordigheid van meisjes op de vorderingen der jongens in voor hen noodzakelijke vakken op den duur een nadeeligen invloed zal moeten uitoefenen. Ik geloof zelfs, dat de meisjes op eene school van meer uitgebreid lager onderwijs, mits die uitsluitend voor haar bestemd is, beter op hare plaats zullen zijn dan op een middelbare jongensschool, hoe goed die ook moge zijn. Daarom heb ik mij dan ook uitdrukkelijk verklaard tegen de toelating van meisjes op de hoogere burgerschool in gemeenten, zooals Zaandam, Sneek on Assen, waar meisjesscholen voor meer uitgebreid lager onderwijs aanwezig zijn. Zijn die scholen niet goed ingericht, dan rust op het gemeentebestuur de verplichting om ze te verbeteren; meent men, dat door zoodanige school niet op voldoende wijze in de behoefte kan worden voorzien, men make er, zoo als reeds op eenige plaatsen is geschied, eene middelbare school van. Het is waar, dit laatste vereischt meer uitgaven voor de gemeente, maar de kans om een Rijkssubsidie te verkrijgen is gelukkig niet afgesloten; de tegenwoordige Minister heeft getoond een open oor te hebben voor de belangen van een degelijk onderwijs voor het vrouwelijk geslacht, en ik kan mij niet voorstellen dat, na de meermalen over deze zaak gehouden gedachtenwisseling, daarin verandering zal komen, wie zich ook aan het roer moge bevinden.

Er zijn nogtans enkele gemeenten, waar geen kans hoegenaamd is, dat er ooit eene behoorlijke school, uitsluitend voor meisjes ingericht, zal kunnen tot stand komen, maar waar zich 
een Rijks hoogere burgerschool van driejarigen cursus bevindt, die door weinig leerlingen bezocht wordt. Ik laat het in 't midden, of het doelmatig was hoogere burgerscholen van driejarigen cursus op te richten in eenige kleine gemeenten, waar het totaal der leerlingen niet dan met moeite een twintigtal kan bedragen; en evenmin of het goed was, op die scholen meisjes toe te laten, om althans een redelijk getal leerlingen te verkrijgen. Maar nu die scholen eenmaal bestaan en als 't ware gemengde scholen geworden zijn, nu zal men wellicht er het meeste nut van trekken, door ze aan die dubbele bestemming te laten blijven beantwoorden; het programma moet dan in zooverre gewijzigd worden, dat het zoo veel mogelijk aan beider behoeften voldoet; daarbij moet dan echter op den voorgrond staan, dat deze scholen niet langer op eene lijn geplaatst kunnen worden met die scholen van driejarigen cursus, die uitsluitend door jongens worden bezocht. Wat de overige scholen betreft, vooral in gemeenten waar eene school van vijfjarigen cursus voor jongens bestaat en een tamelijk getal leerlingen telt, zoo hoop ik, dat daar binnen kort ook voor het vrouwelijk geslacht beter zal worden gezorgd, voordat de jongenssschool den nadeeligen invloed van de toelating van meisjes zal hebben ondervonden. Geschiedt dit niet uit eigen beweging, dan hoop ik dat hij eene herziening van de wet op het middelbaar onderwijs, die wel niet zoolang op zich zal doen wachten, wanneer eenmaal die op het lager onderwijs aan de orde zal zijn geweest, de noodige maatregelen zullen worden genomen om in de toekomst zulke minder goede toepassingen te voorkomen, als waarvan wij in de laatste jaren in dit opzicht getuigen zijn geweest.

Leiden, December 1876.

Steisn Partí. 